Research Article

\title{
Soil-Structure Interaction of Flexible Temporary Trench Box: Parametric Studies Using 3D FE Modelling
}

\author{
Miah Alam, ${ }^{1}$ Omar Chaallal, ${ }^{1}$ and Bertrand Galy $\mathbb{D}^{2}$ \\ ${ }^{1}$ Department of Construction Engineering, Université de Québec, École de Technologie Supérieure, Montreal, QC, Canada H3C 1 K3 \\ ${ }^{2}$ Department of Research, Québec Occupational Health and Safety Research Institute (IRSST), 505 de Maisonneuve Blvd. West, \\ Montreal, Canada H3A $3 \mathrm{C} 2$
}

Correspondence should be addressed to Bertrand Galy; bertrand.galy@irsst.qc.ca

Received 30 March 2021; Accepted 26 August 2021; Published 21 September 2021

Academic Editor: Dimitrios E. Manolakos

Copyright (C) 2021 Miah Alam et al. This is an open access article distributed under the Creative Commons Attribution License, which permits unrestricted use, distribution, and reproduction in any medium, provided the original work is properly cited.

This paper presents the results of two parametric finite-element studies that were carried out using the PLAXIS-3D finite element (FE) computer code. The following objectives and corresponding parameters were considered: (i) to evaluate the soil pressure on the steel trench box shield; the parameters studied were related to soil type and material, and the study considered till, dry sand, wet sand, and sensitive clay soil; (ii) to assess the effect of trench box material and geometry on earth pressure; the parameters studied were related to trench box material (steel versus aluminum) as well as geometry (plate thickness and strut diameter). These studies included simulation of two steel (or aluminum) trench box shields stacked upon each other to cover the total $6 \mathrm{~m}(20 \mathrm{ft})$ deep trench. A Mohr-Coulomb (MC) constitutive material model was chosen for FE analysis (FEA). The FEA results were compared to empirical apparent earth pressure diagrams for a sensitive clay. Comparisons showed that the parameters related to the soil and the trench box have a significant influence on earth pressures.

\section{Introduction}

Evaluation of horizontal earth pressure is of major importance when designing any soil retaining structure $[1,2]$. In the last few years, numerous analytical studies have been carried out to better understand the behaviour of braced excavation protection systems [3]. The trench box shield is different from other shoring systems as it is intended not only to support the trench face but also to protect workers from cave-ins. Trench boxes can be assembled together to create a box system capable of shoring up trenches up to $11 \mathrm{~m}(35 \mathrm{ft})$ deep [4]. This system is relatively easy to transport, assemble, and install in narrow trenches compared to retaining structures built on site such as soldier pile walls. In order to keep the workers safe, shields should not be overloaded [5]. The earth pressure distribution on a shield depends on the shoring, the method of installation, and the type of soil. Many theoretical solutions to estimate earth pressure on a flexible temporary support have been published [6-8]. The Canadian Foundation Engineering Manual
[9] recommends the use of pressure envelopes for excavation trench shields.

Numerical FE and analytical methods helped understanding the behaviour of excavations and trenches with flexible retaining walls. Under a given set of soil conditions, the higher the wall rigidity, the greater was the apparent earth pressure [10]. Hashash and Whittle [11] studied shoring excavations in clay and showed that the earth pressure on a retaining structure (or wall) is a function of the flexibility of the retaining structure and the magnitude of shear deformations at depth. The arching effect in the ground in contact with the shoring also plays a significant role to estimate earth pressure on walls [3, 12-15]. In soft clays, earth pressure on supporting structures is a function that depends on the thickness of the clay layer in the trench bottom, the soil anisotropy, the flexibility of the support, and soil deformation [3].

Horizontal and vertical strut spacing and wall stiffness also influence the earth pressure distribution on excavation support systems (ESS) and have been studied by Bryson 


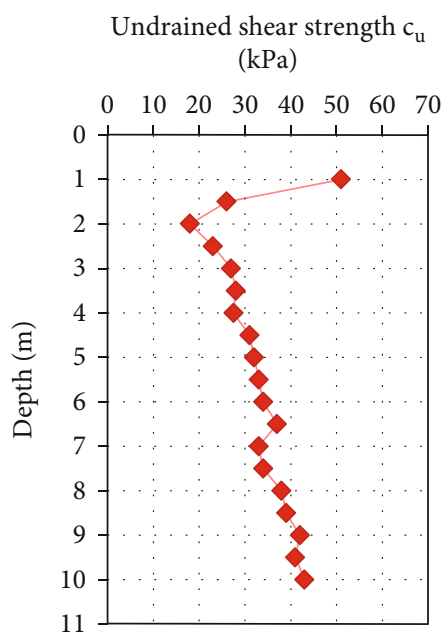

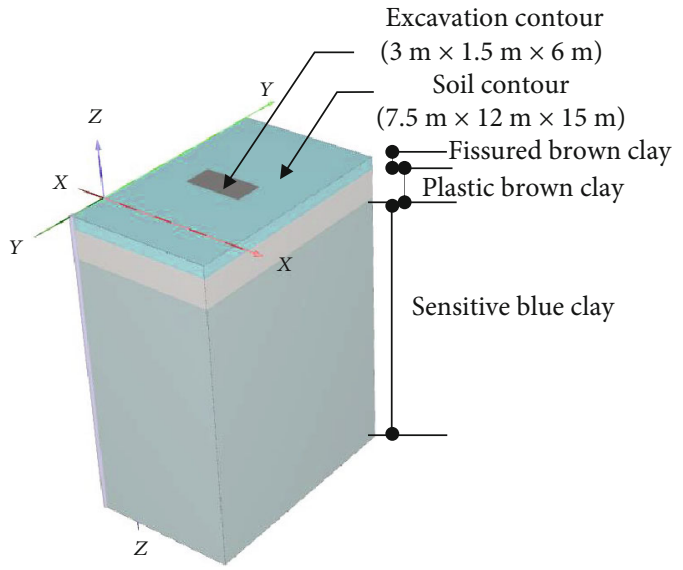

(b)

(a)

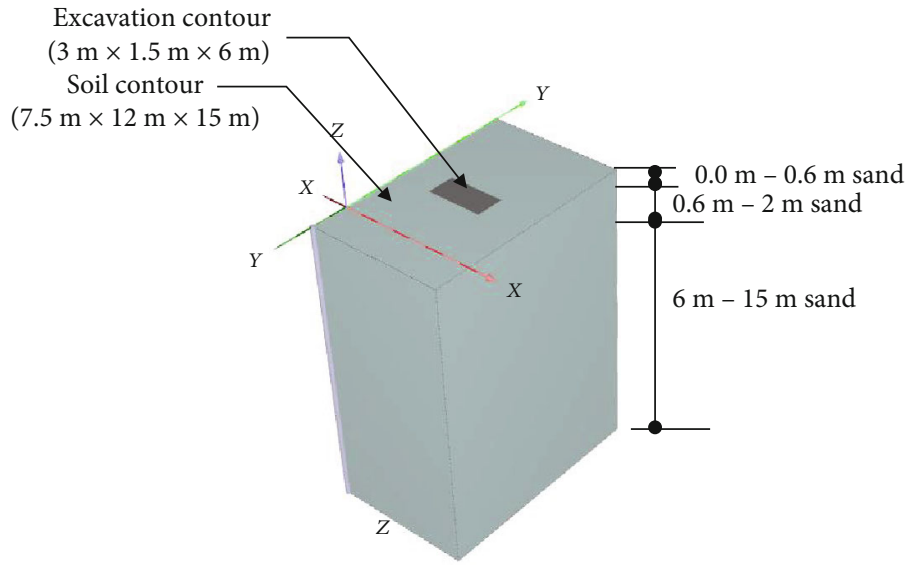

(c)

FIgURE 1: Geometric profile and excavation contour in PLAXIS-3D simulation of trench: (a) experimental values of undrained shear strength of sensitive blue clay (Louiseville clay, data from [33]); (b) PLAXIS-3D model profile for sensitive blue clay (number of soil elements: 23221; MC soil model); (c) PLAXIS-3D model profile for till and dry and wet sand (number of soil elements: 23221; MC soil model).

and Zapata-Medina [16] for three types of clays. These researchers also defined a relative stiffness ratio that relates the stiffness of the soil to the stiffness of the ESS. This ratio depends on multiple factors, including Young's modulus of the wall, Young's modulus of the soil, moment of inertia per unit length of the wall, average vertical support spacing, average horizontal support spacing, excavation depth, total height of the wall, average unit weight of the soil, and undrained shear strength of the soil at the bottom of the excavation. Therefore, the interaction between soil mass and support structure is significant in the development of apparent earth pressure. A recently published paper by Alam et al. [17] showed that modern 3D FEM studies on clay trench SSI focused mainly on a depth greater than $10 \mathrm{~m}$ and on retaining wall or diaphragm wall. Not that many studies have been published on FEM of soil-structure interaction (SSI) with trench boxes in shallow depth trenches of clayey soil. Using 3D FEA and Abaqus software, LaBaw [18] evaluated earth pressure for a standard construction shoring (pneumatic shoring with steel panel) system, which provides an adequate and safe emergency rescue for first responders in medium clay of $2.4 \mathrm{~m}$ depth of trench excavation. Soil-structure interaction analysis is a powerful tool for analyzing, designing systems, and monitoring soil behaviour behind retaining wall under different types of loading in expansive, swelling, and clayey soil. Alam et al. [19] compared a full-scale experimental in situ test of $6 \mathrm{~m}$ depth with 3D FEM to investigate the earth pressure on a flexible temporary trench box shield in soft and sensitive clay soil using PLAXIS-3D software.

This paper presents the influence of soil parameters and shield material type and geometry on the earth pressures on a flexible temporary trench box shield. An FE model using PLAXIS-3D software [20] shows a comprehensive picture of the influence of soil parameters on earth pressures on a flexible temporary trench box shield in till, dry sand, wet sand, and sensitive clay. These FEM analysis results are also compared to published empirical apparent earth pressure diagrams [7]. 
TABLe 1: Plate properties (steel and aluminum) of trench box shield protection used for FE simulation in PLAXIS-3D.

\begin{tabular}{|c|c|c|c|c|c|c|c|c|c|}
\hline \multirow[b]{2}{*}{$\begin{array}{l}\text { Parameter/ } \\
\text { property }\end{array}$} & \multirow[b]{2}{*}{$\begin{array}{c}\text { PLAXIS } \\
\text { nomenclature }\end{array}$} & \multicolumn{4}{|c|}{ Steel plate } & \multicolumn{4}{|c|}{ Aluminum plate } \\
\hline & & $\begin{array}{c}200 \mathrm{~mm} \\
(8 \mathrm{in} .)\end{array}$ & $\begin{array}{c}150 \mathrm{~mm} \\
(6 \mathrm{in} .)\end{array}$ & $\begin{array}{c}100 \mathrm{~mm} \\
(4 \mathrm{in} .)\end{array}$ & $\begin{array}{l}75 \mathrm{~mm} \\
(3 \mathrm{in} .)\end{array}$ & $\begin{array}{c}200 \mathrm{~mm} \\
(8 \mathrm{in} .)\end{array}$ & $\begin{array}{c}150 \mathrm{~mm} \\
(6 \mathrm{in} .)\end{array}$ & $\begin{array}{c}100 \mathrm{~mm} \\
(4 \mathrm{in} .)\end{array}$ & $\begin{array}{c}75 \mathrm{~mm} \\
(3 \mathrm{in} .)\end{array}$ \\
\hline Material type & Type & $\begin{array}{c}\text { Elastic, } \\
\text { isotropic }\end{array}$ & $\begin{array}{c}\text { Elastic, } \\
\text { isotropic }\end{array}$ & $\begin{array}{c}\text { Elastic, } \\
\text { isotropic }\end{array}$ & $\begin{array}{c}\text { Elastic, } \\
\text { isotropic }\end{array}$ & $\begin{array}{c}\text { Elastic, } \\
\text { isotropic }\end{array}$ & $\begin{array}{c}\text { Elastic, } \\
\text { isotropic }\end{array}$ & $\begin{array}{c}\text { Elastic, } \\
\text { isotropic }\end{array}$ & $\begin{array}{l}\text { Elastic, } \\
\text { isotropic }\end{array}$ \\
\hline $\begin{array}{l}\text { Young's } \\
\text { modulus }\end{array}$ & $\mathrm{E} 1\left(\mathrm{kN} / \mathrm{m}^{2}\right)$ & $2 \times 10^{8}$ & $2 \times 10^{8}$ & $2 \times 10^{8}$ & $2 \times 10^{8}$ & $7 \times 10^{7}$ & $7 \times 10^{7}$ & $7 \times 10^{7}$ & $7 \times 10^{7}$ \\
\hline Unit weight & $\gamma\left(\mathrm{kN} / \mathrm{m}^{3}\right)$ & 11.59 & 11.86 & 13.67 & 15.70 & 2.68 & 3.22 & 4.29 & 4.99 \\
\hline Thickness & $d(\mathrm{~m})$ & 0.20 & 0.15 & 0.10 & 0.08 & 0.20 & 0.15 & 0.10 & 0.08 \\
\hline $\begin{array}{l}\text { Poisson's } \\
\text { ratio }\end{array}$ & $v_{12}$ & 0.30 & 0.30 & 0.30 & 0.30 & 0.30 & 0.30 & 0.30 & 0.30 \\
\hline \multirow{3}{*}{$\begin{array}{l}\text { Shear } \\
\text { modulus }\end{array}$} & $G_{12}\left(\mathrm{kN} / \mathrm{m}^{2}\right)$ & $8 \times 10^{7}$ & $8 \times 10^{7}$ & $8 \times 10^{7}$ & $8 \times 10^{7}$ & $2.7 \times 10^{7}$ & $2.7 \times 10^{7}$ & $2.7 \times 10^{7}$ & $2.7 \times 10^{7}$ \\
\hline & $G_{13}\left(\mathrm{kN} / \mathrm{m}^{2}\right)$ & $8 \times 10^{7}$ & $8 \times 10^{7}$ & $8 \times 10^{7}$ & $8 \times 10^{7}$ & $2.7 \times 10^{7}$ & $2.7 \times 10^{7}$ & $2.7 \times 10^{7}$ & $2.7 \times 10^{7}$ \\
\hline & $G_{23}\left(\mathrm{kN} / \mathrm{m}^{2}\right)$ & $8 \times 10^{7}$ & $8 \times 10^{7}$ & $8 \times 10^{7}$ & $8 \times 10^{7}$ & $2.7 \times 10^{7}$ & $2.7 \times 10^{7}$ & $2.7 \times 10^{7}$ & $2.7 \times 10^{7}$ \\
\hline
\end{tabular}

One shield geometry; length $=3 \mathrm{~m}(10 \mathrm{ft})$; height $=3 \mathrm{~m}(10 \mathrm{ft})$; horizontal distance between struts $=2.6416 \mathrm{~m}(104 \mathrm{in}$.).

TABLE 2: Strut properties (steel and aluminum) of trench box shield protection used for FE modelling in PLAXIS-3D.

\begin{tabular}{|c|c|c|c|c|c|c|c|}
\hline $\begin{array}{l}\text { Parameter/ } \\
\text { property }\end{array}$ & PLAXIS nomenclature & $\begin{array}{l}200 \mathrm{~mm} \varnothing \\
(8 \mathrm{in} . \varnothing)\end{array}$ & $\begin{array}{c}\text { Steel strut } \\
100 \mathrm{~mm} \varnothing \\
(4 \mathrm{in} . \varnothing)\end{array}$ & $\begin{array}{c}50 \mathrm{~mm} \varnothing \\
(2 \mathrm{in.} \varnothing)\end{array}$ & $\begin{array}{c}200 \mathrm{~mm} \varnothing \\
(8 \mathrm{in} . \varnothing)\end{array}$ & $\begin{array}{c}\text { Aluminum strut } \\
100 \mathrm{~mm} \varnothing \\
(4 \text { in. } \varnothing)\end{array}$ & $\begin{array}{c}50 \mathrm{~mm} \varnothing \\
(2 \mathrm{in} . \varnothing)\end{array}$ \\
\hline Material type & Type & Elastic & Elastic & Elastic & Elastic & Elastic & Elastic \\
\hline $\begin{array}{l}\text { Young's } \\
\text { modulus }\end{array}$ & $\mathrm{E} 1$ or $\mathrm{E} 2\left(\mathrm{kN} / \mathrm{m}^{2}\right)$ & $2 \times 10^{8}$ & $2 \times 10^{8}$ & $2 \times 10^{8}$ & $7 \times 10^{7}$ & $7 \times 10^{7}$ & $7 \times 10^{7}$ \\
\hline Unit weight & $\gamma\left(\mathrm{kN} / \mathrm{m}^{3}\right)$ & 78.50 & 78.50 & 78.50 & 26.99 & 26.99 & 26.99 \\
\hline $\begin{array}{l}\text { Cross-sectional } \\
\text { area }\end{array}$ & $A\left(\mathrm{~m}^{2}\right)$ & 0.01 & 0.0028 & 0.0010 & 0.01 & 0.0028 & 0.001 \\
\hline \multirow{2}{*}{$\begin{array}{l}\text { Moment of } \\
\text { inertia }\end{array}$} & $I_{2 x x}\left(\mathrm{~m}^{4}\right)$ & $4.41 \times 10^{-5}$ & $3.99 \times 10^{-6}$ & $3.67 \times 10^{-7}$ & $4.41 \times 10^{-5}$ & $3.99 \times 10^{-6}$ & $3.67 \times 10^{-7}$ \\
\hline & $I_{3 y y}\left(\mathrm{~m}^{4}\right)$ & $4.41 \times 10^{-5}$ & $3.99 \times 10^{-6}$ & $3.67 \times 10^{-7}$ & $4.41 \times 10^{-5}$ & $3.99 \times 10^{-6}$ & $3.67 \times 10^{-7}$ \\
\hline \multirow[t]{2}{*}{ Poisson's ratio } & $v_{12}$ & 0.3 & 0.3 & 0.3 & 0.3 & 0.3 & 0.3 \\
\hline & $\begin{array}{l}\text { Outer diameter strut, } \\
\text { do }(\mathrm{mm})\end{array}$ & 215 & 112 & 60 & 215 & 112 & 60 \\
\hline \multirow[t]{3}{*}{$\begin{array}{l}200 \mathrm{~mm} \text { strut } \\
(\mathrm{SCH} 80)\end{array}$} & $\begin{array}{l}\text { Inner diameter strut, di } \\
\qquad(\mathrm{mm})\end{array}$ & 190 & 95 & 48 & 190 & 95 & 48 \\
\hline & Area of strut $\left(\mathrm{m}^{2}\right)$ & $8.24 \times 10^{-3}$ & $2.83 \times 10^{-3}$ & $9.64 \times 10^{-4}$ & $8.24 \times 10^{-3}$ & $2.83 \times 10^{-3}$ & $9.64 \times 10^{-4}$ \\
\hline & $I_{y y}$ or $I_{x x}$ for strut $\left(\mathrm{m}^{4}\right)$ & $4.41 \times 10^{-5}$ & $3.99 \times 10^{-6}$ & $3.67 \times 10^{-7}$ & $4.41 \times 10^{-5}$ & $3.99 \times 10^{-6}$ & $3.67 \times 10^{-7}$ \\
\hline
\end{tabular}

One shield geometry; length $=3 \mathrm{~m}(10 \mathrm{ft})$; height $=3 \mathrm{~m}(10 \mathrm{ft})$; horizontal distance between struts $=2.6416 \mathrm{~m}(104 \mathrm{in}$.).

The influence of shield material type and geometry on the earth pressure in a trench excavation is also presented.

\section{Finite-Element Analyses}

Numerical analyses of ESS performance for recent deep excavation case histories have been done using three-dimensional FE analyses [21-23]. Ou et al. [24] showed that excavationinduced ground movements and soil-structure interactions of ESS are a three-dimensional (3D) phenomenon. FEA software may be a useful tool to obtain in-depth information on the effect of SSI on this type of trench box wall support [17]. To perform this 3D FEA and study the soil-structure interactions, the PLAXIS-3D software was used.

\section{Parameters for FE}

To simulate the trench and steel trench box shield, three sets of parameters were used in PLAXIS-3D: (i) soil model parameters; (ii) structural model parameters for the steel trench box, and (iii) interface parameters.

3.1. Soil Modelling. To simulate the trench, the soil model geometry $((7.5 \mathrm{~m}(25 \mathrm{ft}) \times 12 \mathrm{~m}(40 \mathrm{ft}) \times 15 \mathrm{~m}(50 \mathrm{ft})) \quad$ was more than twice the size of the excavation contour $(3 \mathrm{~m}(10 \mathrm{ft}) \times 1.5 \mathrm{~m}(5 \mathrm{ft}) \times 6 \mathrm{~m}(20 \mathrm{ft}))$ following recommendations by $\mathrm{Hsieh}$ and $\mathrm{Ou}$ [25] for shallow trench excavations (Figure 1(b)). The soil layers were modeled as follows: (i) fissured brown clay from $0 \mathrm{~m}$ to $0.6 \mathrm{~m}(2 \mathrm{ft})$ depth; (ii) plastic brown clay from $0.6 \mathrm{~m}(2 \mathrm{ft})$ to $2 \mathrm{~m}(6.56 \mathrm{ft})$ depth; and (iii) 


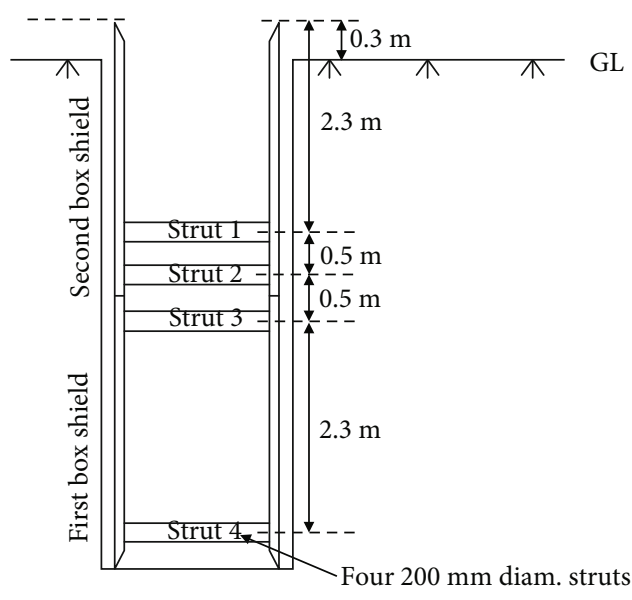

Elevation side 1

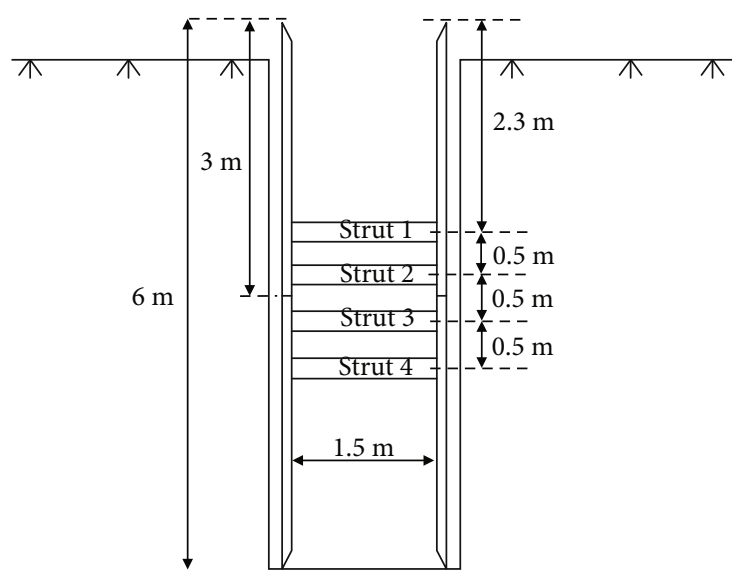

Elevation side 2

Figure 2: Elevation views and strut locations in the two assembled box shields (stacked upon each other) along the trench.

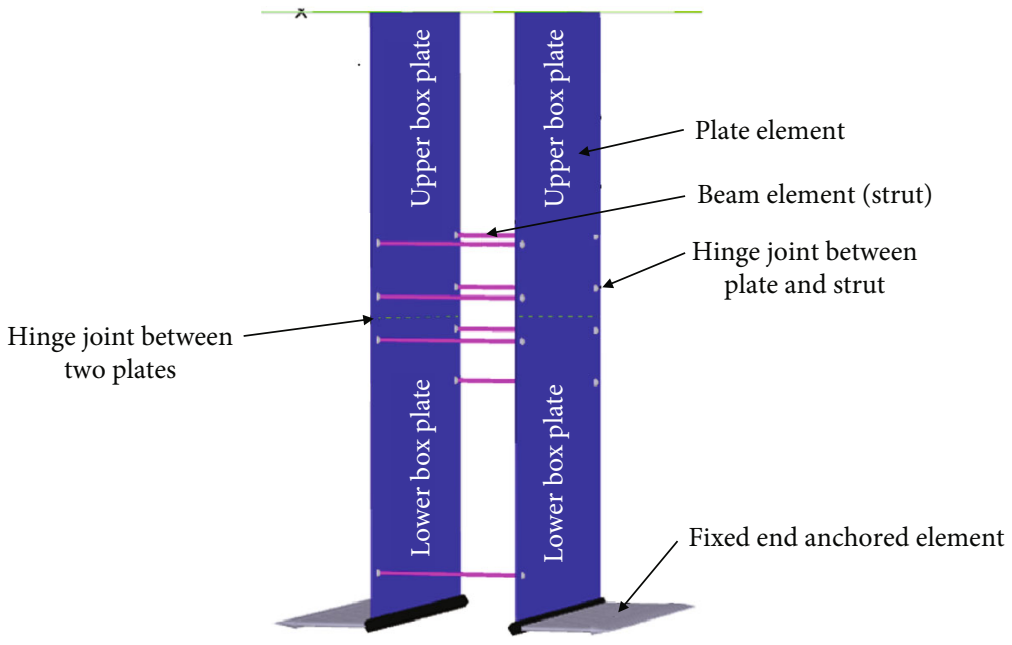

FIgURE 3: Structural simulation view of the two assembled box shields (stacked upon each other) with protection in PLAXIS-3D (number of structural elements: 1050; MC soil model).

sensitive blue clay (Louiseville clay) from $2 \mathrm{~m}(6.56 \mathrm{ft})$ to $15 \mathrm{~m}$ (50 ft) depth, in accordance with the stratigraphic profile of the Louiseville soil [19]. Soil strength properties were selected carefully as they are a key factor in ESS performance [26]. The in situ value of undrained shear strength shown in Figure 1(a) was used in this FEA. On the other hand, till, dry sand, and wet sand layers were modelled using 0.0 to $15 \mathrm{~m}$ depths of the properties of each type of sand, as shown in Figure 1(c), with varying stiffness parameters along the depth.

3.2. Structural Modelling. The stiffness of an ESS is a function of the flexural rigidity of the wall element, the structural stiffness of the support elements, the type of connections between the wall and the supports, and the vertical and horizontal spacing of the support system [16]. In the FE model, the two trench steel shields are stacked upon each other to cover the total depth $(6 \mathrm{~m}(20 \mathrm{ft}))$ of excavation. The geometrical dimensions and mechanical properties are given in Tables 1 and 2, and the positions and locations of the struts used for simulation are shown in Figure 2. To account for the "sandwich-type" construction of the trench box plates, unit weight $(\gamma)$ of the trench box plates was calculated from the real weight of the trench box used for experimental test, divided by its real volume. The real thickness of sandwich plates was the PLAXIS-3D input for the plate geometry. Four different thicknesses were considered in the parametric study: $200 \mathrm{~mm}$ ( $8 \mathrm{in}.), 150 \mathrm{~mm}$ (6 in.), $100 \mathrm{~mm}$ (4 in.), and $75 \mathrm{~mm}$ ( 3 in.). For the struts, cross-sectional area $(A)$ and moment of inertia $(I)$ were calculated from the original strut diameter, while Young's modulus $(E)$ and unit weight $(\gamma)$ were taken from the SCH80 chart. The vertical positions of the struts were kept different on both sides of the steel trench box as per the in situ experimental test at the Louiseville site. Note that $200 \mathrm{~mm}(8 \mathrm{in}$.) strut diameter and $100 \mathrm{~mm}$ (4 in.) shield plate were used for till, dry sand, wet sand, and sensitive clay soil analysis, whereas other dimensions were used for geometric influence FE analysis.

In the PLAXIS-3D simulation, the steel trench box walls were modelled as "plate elements" and the struts as "beam 

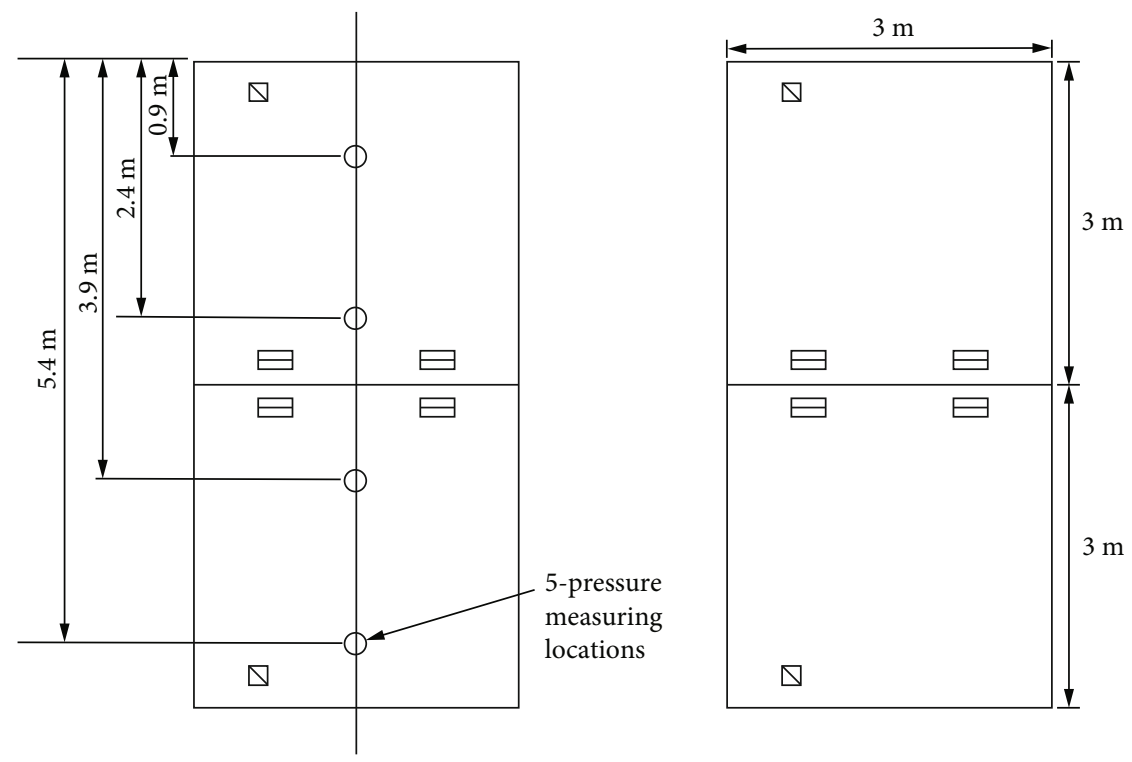

FIgURE 4: Trench box supporting wall side views and pressure measuring locations from the top.

elements." "Hinge joints" were used between the two box shields (stacked upon each other) to represent the experimental setup (Figures 3). The joints between struts and plates were also simulated as "hinge joints" as per the experimental setup (Figures 3). In the in situ experiment, when the $1^{\text {st }}$ box is inserted into the soil and the upper box $\left(2^{\text {nd }}\right.$ box) is pushed on top of the lower box ( $1^{\text {st }}$ box) using an excavator, the soil provide the relevant lateral support for the bottom end of the lower trench box ( $1^{\text {st }}$ box). Alam et al. [27] noticed in their experimental work that the bottom end part of the shield (approximately $300 \mathrm{~mm}$ ) was embedded into the soil. Therefore, this part of the lower box acted more likely as a "fixed-end support" and was represented by a "fixed-end anchored element" in the FE model (Figure 3). The pressure measuring locations are shown in Figure 4. To analyze the nonlinear stress-strain behaviour of the soil, a Mohr-Coulomb (MC) constitutive material model was chosen in this study.

3.3. Generating the Mohr-Coulomb (MC) Model. The MohrCoulomb (MC) model is a simple and widely used linear elastic perfectly plastic model. Tables 3 and 4 shows soil properties for the sensitive blue clay (Louiseville clay), till, dry sand, and wet sand model parameters used for FE modelling in PLAXIS-3D. The soil stiffness modulus $(E)$ at different depths for sensitive blue clay (Louiseville clay) was calculated from the shear strength $\left(C_{\mathrm{u}}\right)$ using the equation proposed by R. Peck, The Selection of Soil Parameters for the Design ofFoundations. Second Nabor Carrillo Lecture, Mexican Societyfor Soil Mechanics, Mexico, 1975.:

$$
E=600 * C_{\mathrm{u}} .
$$

Using Equation (1), $E$ was calculated for each layer, and the average values of $E\left(E_{\text {avg }}\right)$ were taken as PLAXIS-3D input for the $1 \mathrm{~m}$ soil layers (further details are provided in [19]). This method to evaluate $E$ is practical as an in situ shear strength testing and is very common in engineering practice, allowing thereby to practicing engineers to have access to those representative geotechnical properties. The total stress soil properties for sensitive blue clay (Louiseville clay) are presented in Table 3. For till, dry sand, and wet sand, which have different unit weights $(\gamma)$ of sand and angles of friction $(\varphi)$, these soil parameters for the MC model were used for parametric FE modelling, as shown in Table 3. For the different sandy soil stiffness moduli, the maximum shear modulus, $G_{\max }$, was calculated for each meter of depth using Equation (2), developed by Seed and Idriss [28]:

$$
G_{\max }=1000 K_{2 \max }\left(\sigma_{\mathrm{m}}^{\prime}\right)^{0.5},
$$

where $\sigma_{\mathrm{m}}^{\prime}$ is effective mean stress $=\left(\sigma_{\mathrm{v}}^{\prime}+2 \sigma_{\mathrm{h}}^{\prime}\right) / 3 ; \sigma_{\mathrm{v}}^{\prime}$ is vertical effective stress; $\sigma_{\mathrm{h}}^{\prime}$ is horizontal effective stress; $\sigma_{\mathrm{h}}^{\prime}=K_{0} \times \sigma_{\mathrm{v}}^{\prime}$; and $K_{0}$ is coefficient of earth pressure at rest. $K_{2 \max }$ is an empirical factor that varies with void ratio. The values of $K_{2 \max }$ considered in this study for the different soil types are presented in Table 3. Then, these calculated maximum shear modulus values $\left(G_{\max }\right)$ for till, dry sand, and wet sand were used separately for each type of soil for drainage analysis in PLAXIS-3D simulation models.

Soil stiffness parameters vary with the depth. Therefore, anisotropy is considered for the soil models, which are subdivided into $1 \mathrm{~m}$ deep layers below the first 2 meters, and the parameters $E$ and $G_{\max }$ are computed for each layer using Equations (1) and (2), respectively. Unloading/reloading stiffness parameter is given by $G_{\max }$ and considered elastic, as in Karlsrud and Andresen's [3] study. Further details related to the Louiseville clay soil model can be found in Alam et al. [19].

3.4. Interface Model. Trench box steel plate forms a smooth wall, but in construction practice, it is impossible to find a 
TABLe 3: Soil properties for sensitive blue clay, till, and dry and wet sand model parameters used for FE modelling in PLAXIS-3D.

\begin{tabular}{|c|c|c|c|c|c|}
\hline Parameter/property & $\begin{array}{c}\text { PLAXIS } \\
\text { nomenclature }\end{array}$ & Sensitive blue clay & Till & $\begin{array}{l}\text { Dry sand, } \\
\text { medium density }\end{array}$ & $\begin{array}{c}\text { Wet sand, } \\
\text { medium density }\end{array}$ \\
\hline Depth of layer & $\mathrm{m}$ & $0.0-15$ & $0.0-15$ & $0.0-15$ & $0.0-15$ \\
\hline Material model & Model & $\mathrm{MC}$ & $\mathrm{MC}$ & MC & MC \\
\hline Drainage type & Type & Undrained & Drained & Drained & Drained \\
\hline Unit wt. above phreatic level & $\gamma_{\text {unsat }}\left(\mathrm{kN} / \mathrm{m}^{3}\right)$ & 16 & 21.5 & 19.5 & 19.5 \\
\hline Unit wt. below phreatic level & $\gamma_{\text {sat }}\left(\mathrm{kN} / \mathrm{m}^{3}\right)$ & 17 & - & - & 19.5 \\
\hline $\begin{array}{l}\text { Maximum elastic/shear } \\
\text { modulus }\end{array}$ & $\begin{array}{c}E_{\mathrm{avg}} / G_{\max }(\mathrm{kN} / \\
\left.\mathrm{m}^{2}\right)\end{array}$ & $\begin{array}{c}\left(E_{\mathrm{avg}} \text { as per Equation }\right. \\
(1))\end{array}$ & $\left(G_{\max }\right.$ as per Equation & $\begin{array}{c}\left(G_{\max } \text { as per Eq. }\right. \\
(2))\end{array}$ & $\left(G_{\max }\right.$ as per Equation \\
\hline$K_{2 \max }$ & - & - & 70 & 52 & 52 \\
\hline Cohesion & $C_{\mathrm{ref}}^{\prime}\left(\mathrm{kN} / \mathrm{m}^{2}\right)$ & See Table 4 & 5 & 5 & 5 \\
\hline Frictional angle & $\phi\left(^{\circ}(\right.$ degree $\left.)\right)$ & See Table 4 & 42 & 35 & 35 \\
\hline Dilatancy angle & $\Psi\left({ }^{\circ}\right.$ (degree $\left.)\right)$ & 0 & 0 & 0 & 0 \\
\hline Poisson's ratio & $v_{\mathrm{ur}}^{\prime}$ & 0.3 & 0.3 & 0.3 & 0.3 \\
\hline $\begin{array}{l}\text { Interface strength reduction } \\
\text { factor }\end{array}$ & $R_{\text {inter }}$ & 0.5 & 0.65 & 0.65 & 0.65 \\
\hline Initial $K_{0}$ determination & $K_{0}$ & 0.53 & 1.0 & 0.43 & 0.43 \\
\hline Soil type & & Very fine & & & \\
\hline$<2 \mu \mathrm{m}$ & $\%$ & 74 & 10 & 10 & 10 \\
\hline $2 \mu \mathrm{m}-50 \mu \mathrm{m}$ & $\%$ & 11 & 13 & 13 & 13 \\
\hline
\end{tabular}

TABle 4: Parameters for different layers of sensitive blue clay (Louiseville clay, data from [34]).

\begin{tabular}{lcc}
\hline Soil layer & Parameters in total stresses & Drained condition \\
\hline Fissured brown clay $(0$ to $0.6 \mathrm{~m})$ & $c^{\prime}=5 \mathrm{kPa}$ and $\phi^{\prime}=28^{\circ}$ & Drained \\
Plastic brown clay $(0.6$ to $2 \mathrm{~m})$ & $c=c_{\mathrm{u}}$ (Figure $\left.1(\mathrm{a})\right)$ and $\phi=0^{\circ}$ & Undrained \\
Sensitive blue clay $(2$ to $15 \mathrm{~m})$ & $c=c_{\mathrm{u}}$ (Figure $\left.1(\mathrm{a})\right)$ and $\phi=0^{\circ}$ & Undrained \\
\hline
\end{tabular}

smooth wall that has no roughness [29]. Interfaces were added for proper modelling of SSI. They represent a thin zone of shearing material at the contact between a plate element and the surrounding soil. Negative and positive interfaces were added on either side of a plate surface (Figure 5(c)). The interaction between plate elements and soil elements was expressed by a strength reduction factor $\left(R_{\text {inter }}\right)$, which relates the soil strength (friction angle and cohesion) to the interface strength (wall friction and adhesion). According to PLAXIS manual, recommended values for $R_{\text {inter }}$ are $2 / 3$ for fissured brown clay and $<2 / 3$ for plastic brown and sensitive blue soft clay [20] (Table 3 ). The interface was assigned a virtual thickness that varied with mesh type and in this case was $103 \times 10^{-3} \mathrm{~m}$. The interface element consisted of pairs of nodes that were compatible with a sixnode triangular side of a soil element or a plate element [20].

For till and dry sand analysis, water was not considered (water level below the bottom of the excavation). For the wet sand, water table was considered at $2.5 \mathrm{~m}$ below the top of soil. Inside the trench, water was considered pumped out (to allow work inside the trench). Therefore, water was present in the surrounding soil of excavation, creating thereby a horizontal pressure on the wall of trench box shield outside the trench in addition to soil pressure.
3.5. Mesh Generation. Medium coarse 10-noded elements were used Figures 5(a) and 5(b). The mesh has a total of 24271 elements, i.e., 23221 soil elements and 1050 structural elements.

\section{Construction Steps and Phases in PLAXIS-3D Simulation for Sensitive Blue Clay}

Construction sequence has a significant impact on the lateral loads acting on a flexible retaining structure [30]. The model includes a step-by-step excavation sequence, including the structural element insertion into the excavation. The excavation sequence is summarized in Table 5, and construction and excavation steps are shown in Figure 6 for sensitive blue clay.

4.1. Calculations with Different $K_{0}$. In practice, $K_{0}$ for a drained soil is computed with Jaky's [31] empirical expression. In an overconsolidated soil, $K_{0}$ would be expected to be larger than the value given by Jaky's formula. Hamouche et al. [32] evaluated the in situ coefficient of earth pressure at rest for Louiseville sensitive blue clay. Three values of $K_{0}$ $(0.55,1$, and 1.5$)$ were selected to evaluate the effect on the soil pressure on the trench box as follows: (i) $K_{0}=0.55$ 


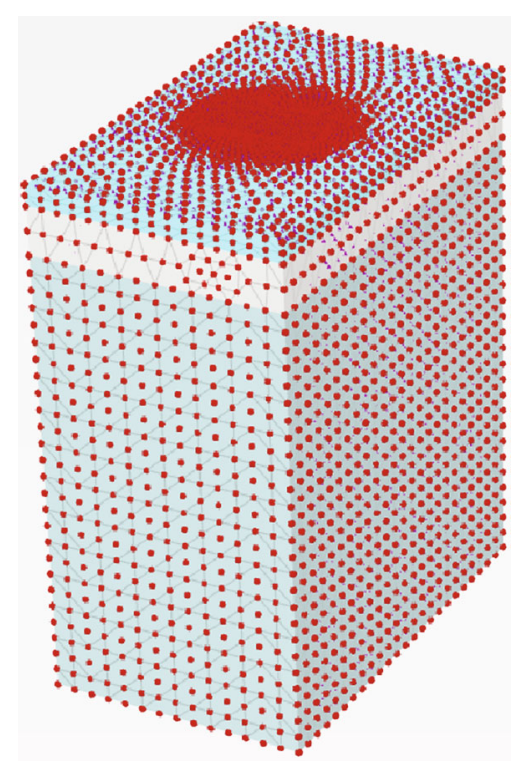

(a) Soil mesh

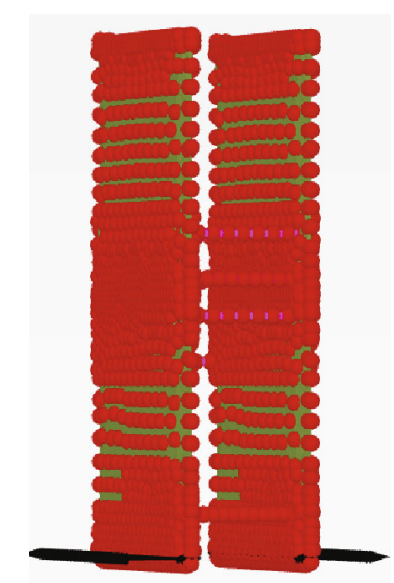

(b) Structural mesh of trench box inside the soil

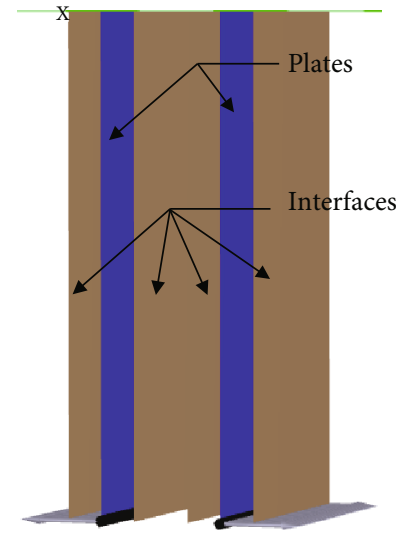

(c) Interfaces

FIgure 5: Soil and structural mesh elements and interfaces in PLAXIS-3D simulation.

TABLE 5: Construction sequence of FE modelling for sensitive blue clay in PLAXIS-3D.

\begin{tabular}{lcc}
\hline Phase & In the model & Drainage \\
\hline Phase 0 & Only soil elements $($ no structure $)$ & $K_{0}$ procedure \\
Phase 1 & Excavation ( $1^{\text {st }}$ layer, depth: $\left.0.6 \mathrm{~m}\right)$ fissured brown clay & Drained \\
Phase 2 & Excavation $\left(2^{\text {nd }}\right.$ layer: 0.6 to $\left.2 \mathrm{~m}\right)$ brown clay & Plastic: undrained $\mathrm{B}^{1}$ (soil model) \\
Phase 3 & Adding structural element & Plastic: undrained $\mathrm{B}^{1}$ (soil model) \\
Phase 4 & Excavation $\left(3^{\text {rd }}\right.$ layer: $2 \mathrm{~m}$ to $6 \mathrm{~m}$ ) sensitive blue clay & Plastic: undrained $\mathrm{B}^{1}$ (soil model) \\
\hline
\end{tabular}

${ }^{1}$ In the undrained (B) drainage type, modelling of undrained behaviour using effective parameters for stiffness and undrained shear strength parameters is allowed.

represents a common value for normally consolidated eastern Canada clays (with $\phi^{\prime}=27^{\circ}$ ); (ii) $K_{0}=1$ represents a clay in undrained conditions (when $\phi=0$ ); and (iii) $K_{0}=1.5$ was determined experimentally at $6 \mathrm{~m}$ depth by Hamouche et al. [32] for Louiseville clay. Figure 7 shows the value of soil pressure computed with different $K_{0}$ values using the PLAXIS model.

\section{Construction Steps and Phases in PLAXIS-3D Simulation for Till, Dry Sand, and Wet Sand}

To simulate till and dry sand, the water table was maintained below excavation level, and $2.5 \mathrm{~m}$ below the ground for wet sand, which was the lowest level recorded in experimental testing [19]. Then, the PLAXIS-3D simulation model was implemented to perform the analysis. However, when the cohesion value $C=0 \mathrm{kPa}$ was used, the PLAXIS-3D simulation showed that the excavation steps failed because the soil bodies failed. Hence, trial methods were used, increasing cohesion values in the range of $4-5 \mathrm{kPa}$. Thereafter, the excavation steps proceeded with the cohesion value of $5 \mathrm{kPa}$, and the model was run for analysis. However, the numerical analysis results showed that the soil pressure on the box shield was notably low, and at a certain depth, the soil ceased to be in an elastic state.

When only the initial phase was used (meaning no excavation steps, installing the structure inside the soil straight away, and then removing the soil inside the trench box), the soil stresses were more reliable and comparable with the Terzaghi and Peck [7] apparent earth pressure curve for granular soil. It was observed that till created more stress on the shield than any other soil type. Dry sand yielded a higher soil pressure than wet sand except at $5.4 \mathrm{~m}$ depth, as shown in Figure 8. All the FEA results were compared with the Terzaghi and Peck [7] curves for till, dry and wet sand, and sensitive blue clay (Louiseville clay), as shown in Figure 8.

\section{Parametric Studies for Steel and Aluminum Trench Box for Plate and Strut Geometry}

For this type of parametric study, the M-C model for sensitive blue clay (Louiseville clay) was chosen for analysis. The objective was to evaluate the influence of material type and geometry on the earth pressure on the temporary excavation trench box shield. Three scenarios were considered: (i) trench box materials (steel and aluminum), (ii) steel 


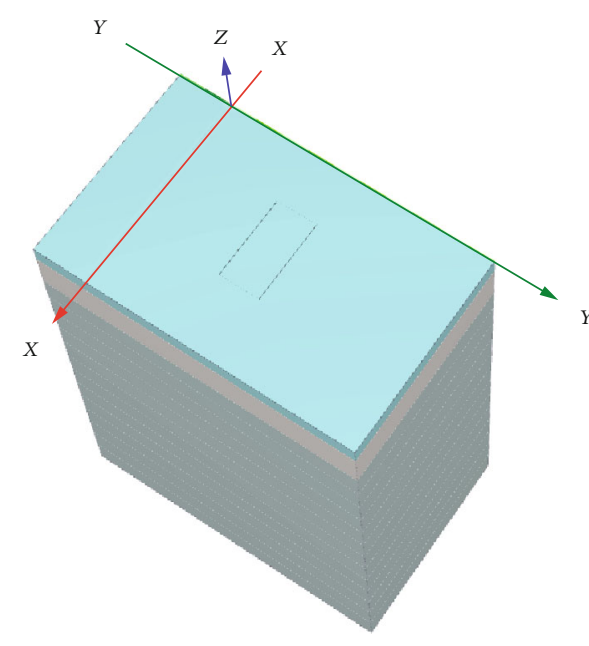

(a) Step 0 (initial phase)

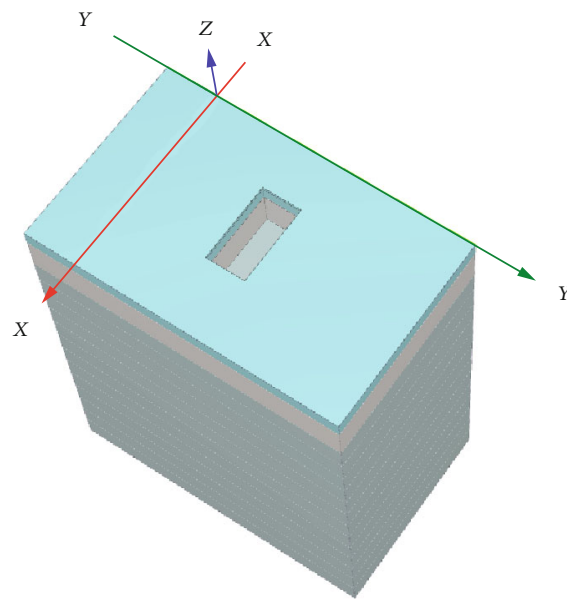

(c) Step 2 (Phase 2)

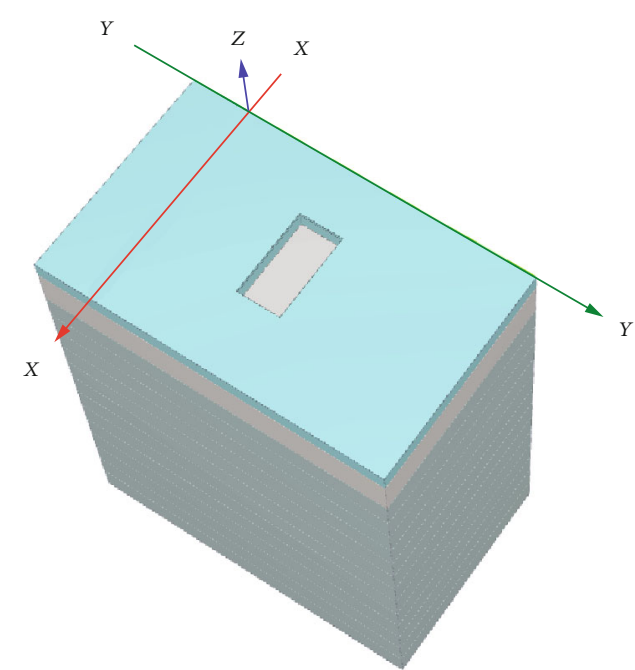

(b) Step 1 (Phase 1)

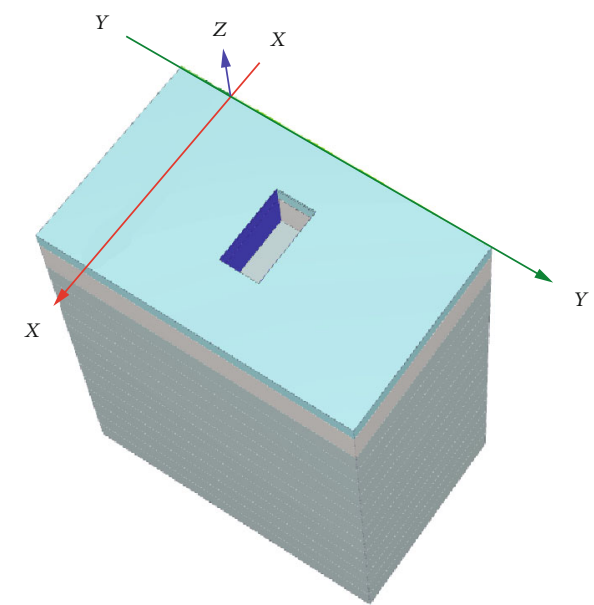

(d) Step3 (Phase 3)

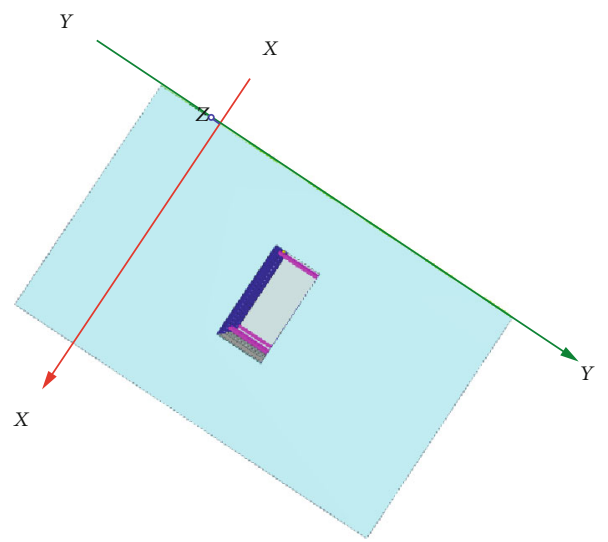

(e) Step 4 (Phase 4)

FIGURE 6: PLAXIS-3D simulation of the construction steps.

trench box with different plate thicknesses and strut diameters, and (iii) aluminum trench box with different plate thicknesses and strut diameters. A total of 16 trench box configurations were considered ( 4 thicknesses $\times 2$ materials $\times 2$ strut diameters). Table 6 shows the simulation matrix, which was used for the PLAXIS-3D simulations.

\section{Overall Results and Comparisons}

The Terzaghi and Peck [7] curves for till, dry sand, and wet sand were compared with the FEA result for homogeneous granular soils (Figure 8). A detailed comparison of the sensitive blue clay (Louiseville clay) FEA results to 


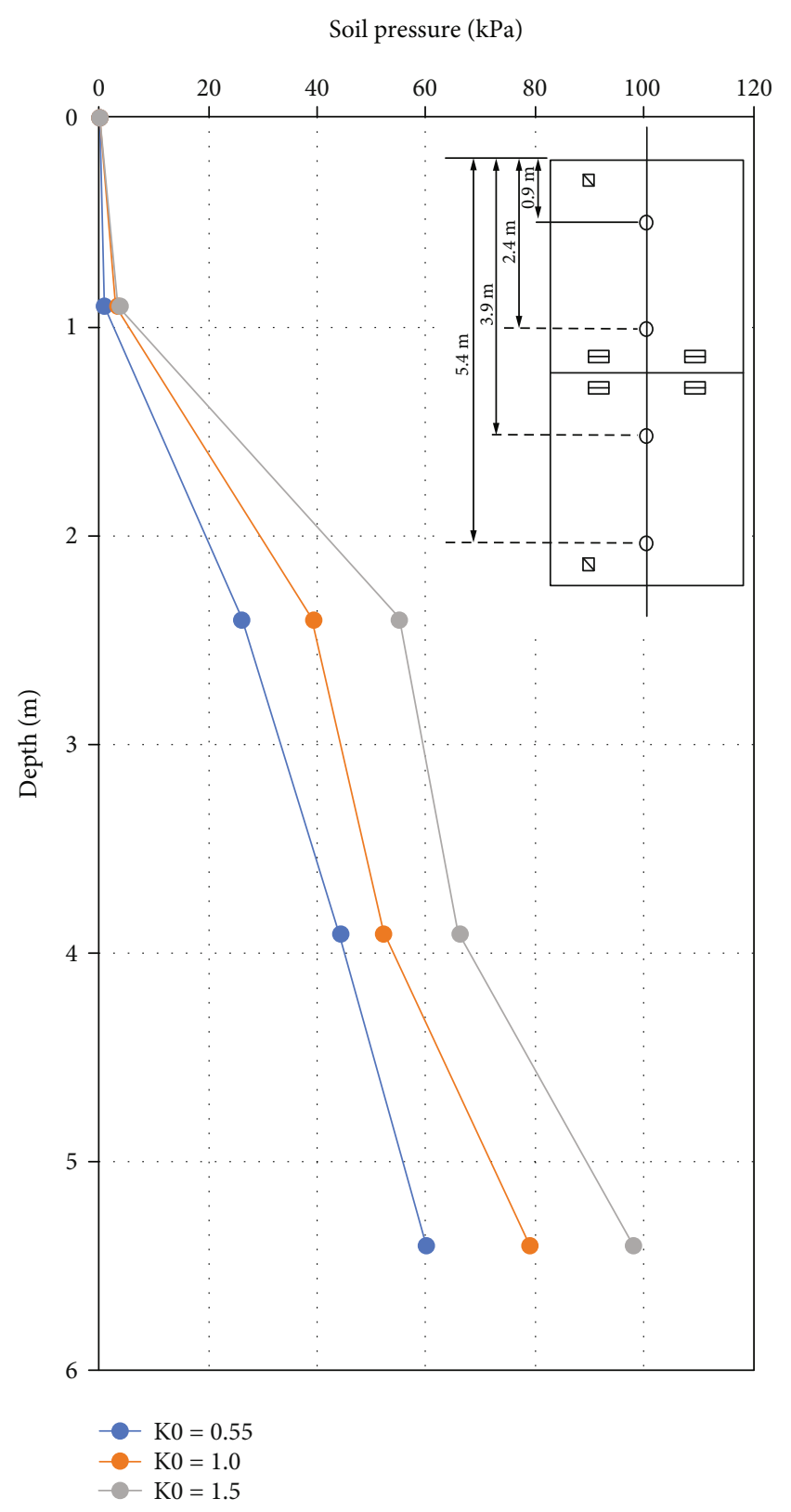

FIGURE 7: Soil pressure at different depths of trench with different $K_{0}$ values.

theoretical apparent earth pressure is provided in Alam et al. [19]. It is evident that when the trench box material type and geometry changed, the earth pressure on the temporary shield also changed for the same soil type. The results are summarized in Figure 8 for different types of soil and in Table 7 and Figures 9-12 for different materials and geometries. Based on these tables and figures, the following comparative observations can be made:

(1) Till, dry sand, and wet sand versus theoretical predictions: the "Peck" curve was calculated from apparent earth pressure according to the Terzaghi and Peck [7] method (TPM). From the "Peck" curve, values for till, dry sand, and wet sand were overesti- mated in the upper part compared to the deeper part of the trench

(2) Steel versus aluminum trench box shield: under the same soil condition (Louiseville clay), a significant difference in earth pressures between the steel and aluminum temporary shields was observed. The maximum undrained total stresses decreased by $40.6 \%$ when shifting from a steel to an aluminum trench box shield with the same geometry of $100 \mathrm{~mm}$ (4 in.) plate thickness and $200 \mathrm{~mm}$ (8 in.) strut diameter

(3) Steel versus aluminum trench box shield plate thickness: reduction of shield plate thickness influenced soil pressure on both steel and aluminum trench box shields under the same soil condition (Louiseville clay). The FEA results showed that changing the plate thickness from $200 \mathrm{~mm}$ (8 in.) to $150 \mathrm{~mm}$ (6in.), $150 \mathrm{~mm} \mathrm{(6in.)} \mathrm{to} 100 \mathrm{~mm}$ (4 in.), and $100 \mathrm{~mm}$ (4 in.) to $75 \mathrm{~mm}$ (3 in.) resulted in a maximum decrease in soil pressure on the steel trench box of $5.5 \%, 9.2 \%$, and $17 \%$. These values reached $35.11 \%, 33.67 \%$, and $13.5 \%$ for aluminum trench box for the same $200 \mathrm{~mm}$ ( 8 in.) strut diameter

(4) Steel versus aluminum trench box shield strut diameter (Louiseville clay): once again, a reduction in shield strut diameter influenced soil pressure on both steel and aluminum shields under the same soil condition. Furthermore, FEA results showed that changing the strut diameter from $200 \mathrm{~mm}$ ( 8 in.) to $100 \mathrm{~mm}$ ( 4 in.) gave a maximum of $1.12 \%, 1.9 \%$, and $8.4 \%$ decrease in soil pressure on the steel trench box and $2.7 \%, 4.0 \%$, and $9.5 \%$ on the aluminum trench box shield, respectively, for $200 \mathrm{~mm}$ ( $8 \mathrm{in}$.), $150 \mathrm{~mm}$ (6in.), and $100 \mathrm{~mm}$ (4in.) plate thickness for the same soil condition

From the above discussions, it is apparent that soil pressure on the trench box shield depends not only on soil type but also on soil-structure stiffness. For the same material type and geometry, a trench box experiences different scales of pressure for different soil types. On the other hand, a given type of soil trench box experiences different scales of pressure for different types of material and geometry. Wall deformation shows some bulging as a result of flexure, and the level of bulging depends on the stiffness of the wall support system. A wall with a higher rigidity experiences less deformation and creates greater apparent earth pressure in a particular homogeneous soil. The results of these nonlinear parametric numerical models, in which only the wall (or trench box) stiffness (steel to aluminum) varied, show that the shape of the earth pressure distribution evolves from higher to lower values (i.e., $40.6 \%$ decrease of undrained total stresses) under a given set of soil conditions (i.e., the higher the wall rigidity, the greater the apparent earth pressure). Therefore, it is evident that soil pressure depends not only on soil 


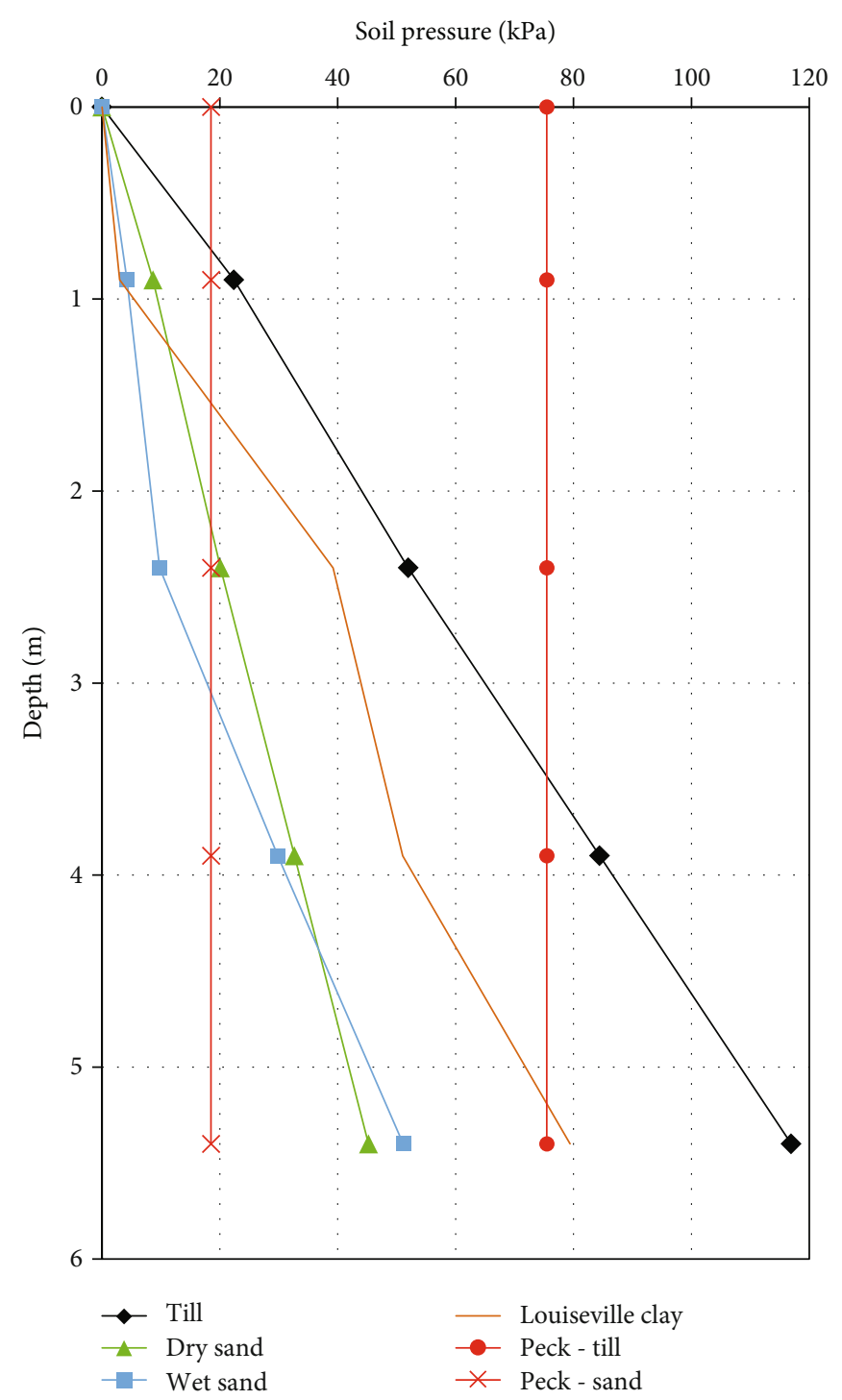

Figure 8: Comparisons of soil pressure for different types of soil by numerical analysis with theoretical values in the trench.

TABLe 6: Simulation matrix for parametric study of the trench box.

\begin{tabular}{|c|c|c|}
\hline \multirow{2}{*}{ Wall thickness of the box } & \multicolumn{2}{|c|}{ Strut diameter } \\
\hline & Steel box & Aluminum box \\
\hline $75 \mathrm{~mm}(3 \mathrm{in})$. & $200 \mathrm{~mm}(8 \mathrm{in}.) \varnothing$ and $50 \mathrm{~mm}(2$ in. $) \varnothing$ & $200 \mathrm{~mm}$ (8 in.) $\varnothing$ and $50 \mathrm{~mm}(2$ in.) $\varnothing$ \\
\hline $100 \mathrm{~mm}$ ( 4 in.) & $200 \mathrm{~mm}$ (8 in.) $\varnothing$ and $100 \mathrm{~mm}$ (4 in.) $\varnothing$ & $200 \mathrm{~mm}$ (8 in.) $\varnothing$ and $100 \mathrm{~mm}$ (4 in.) $\varnothing$ \\
\hline $150 \mathrm{~mm}$ (6 in.) & $200 \mathrm{~mm}$ (8 in.) $\varnothing$ and $100 \mathrm{~mm}(4$ in.) $\varnothing$ & $200 \mathrm{~mm}$ (8 in.) $\varnothing$ and $100 \mathrm{~mm}$ (4 in.) $\varnothing$ \\
\hline $200 \mathrm{~mm}(8 \mathrm{in})$. & $200 \mathrm{~mm}$ (8 in.) $\varnothing$ and $100 \mathrm{~mm}$ (4 in.) $\varnothing$ & $200 \mathrm{~mm}$ (8 in.) $\varnothing$ and $100 \mathrm{~mm}$ (4 in.) $\varnothing$ \\
\hline
\end{tabular}

$1 \mathrm{in.}=25 \mathrm{~mm}$.

stiffness but also on the stiffness of the trench box. Classical theories overestimate soil pressure in the upper part of the trench and may not be safe for the deeper part. When designing a trench box shield, the classical apparent earth pressure envelope may not be the only source of information. Adding in situ measurements and numerical data would be a better idea.

\section{Conclusions}

The parametric FE studies presented in this paper involve simulation of two trench box shields stacked upon each other to cover the total depth of the $6 \mathrm{~m}(20 \mathrm{ft})$ trench in sensitive clay and sandy soils, with the PLAXIS 3D FE computer code. The goal of these studies is to gain an insightful picture of the effect 


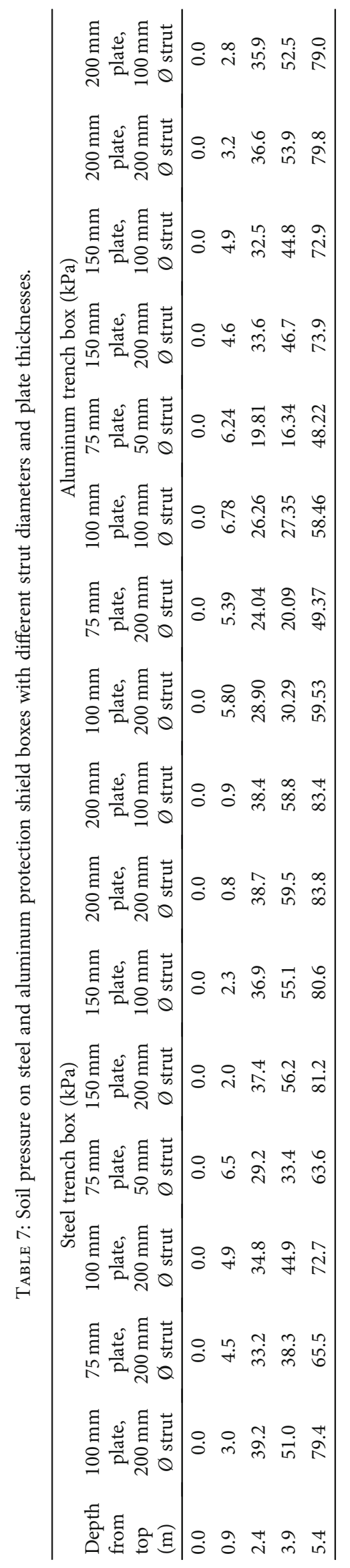




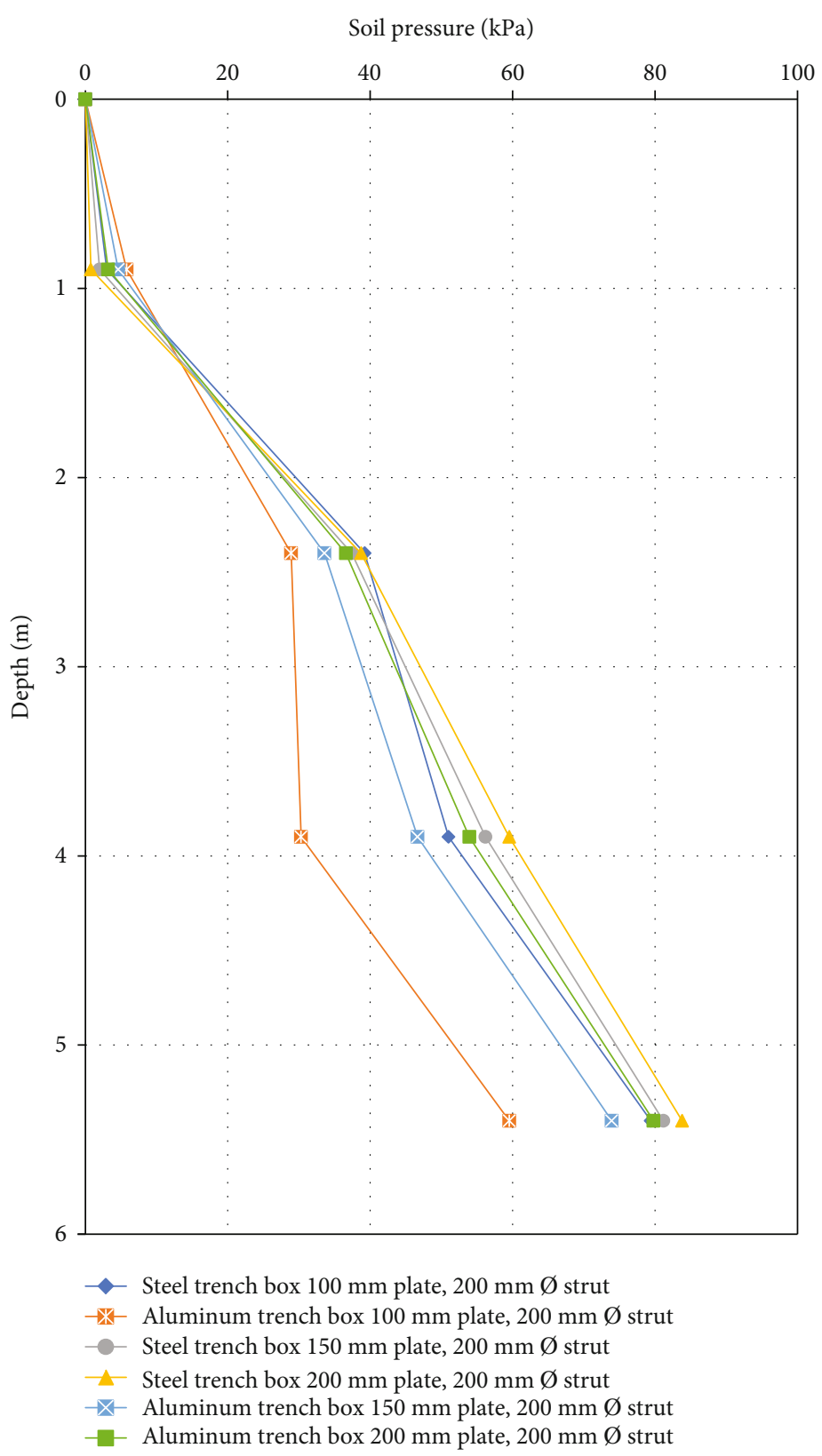

FIgURE 9: Soil pressure (Louiseville clay) on steel versus aluminum trench box shields with the same geometry.

of (i) soil parameters on the steel trench box shield for till, dry sand, wet sand, and sensitive clay soil and (ii) the trench box material type (steel or aluminum) and geometry on the earth pressure. The FEM analysis results are also compared to published empirical apparent earth pressure diagrams.

Based on the FEA results, the following observations can be made:

(i) Earth pressure on a steel trench box for till, dry sand, and wet sand seems to be underestimated by Terzaghi and Peck [7] earth pressure diagrams for the lower part of the trench box (below $4 \mathrm{~m}$ depth in the case of till and below $3 \mathrm{~m}$ depth in the case of dry and wet sand) (ii) A significant difference in earth pressure was found between the steel and aluminum temporary shields. The maximum undrained total stresses decreased by $40.6 \%$ when shifting from a steel to an aluminum shield having the same geometry

(iii) FEA results showed that changing plate thickness from $100 \mathrm{~mm}$ (4in.) to $75 \mathrm{~mm}$ ( $3 \mathrm{in}$.) resulted in a maximum $17 \%$ decrease in soil pressure on steel and a $33.67 \%$ decrease on aluminum trench box shields for the same type of soil

(iv) Changing the strut diameter from $200 \mathrm{~mm}$ (8 in.) to $100 \mathrm{~mm}$ (4 in.) resulted in a maximum $8.4 \%$ decrease in soil pressure on steel and a maximum 


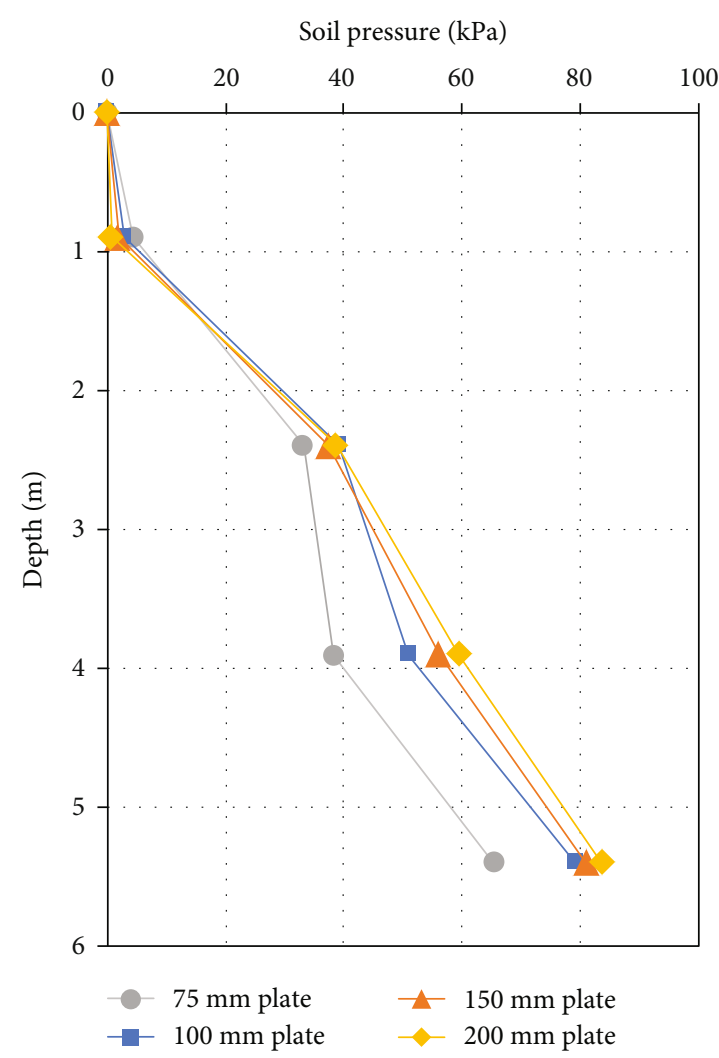

(a) Soil pressure on steel box shield of $200 \mathrm{~mm} \emptyset$ struts Soil pressure $(\mathrm{kPa})$

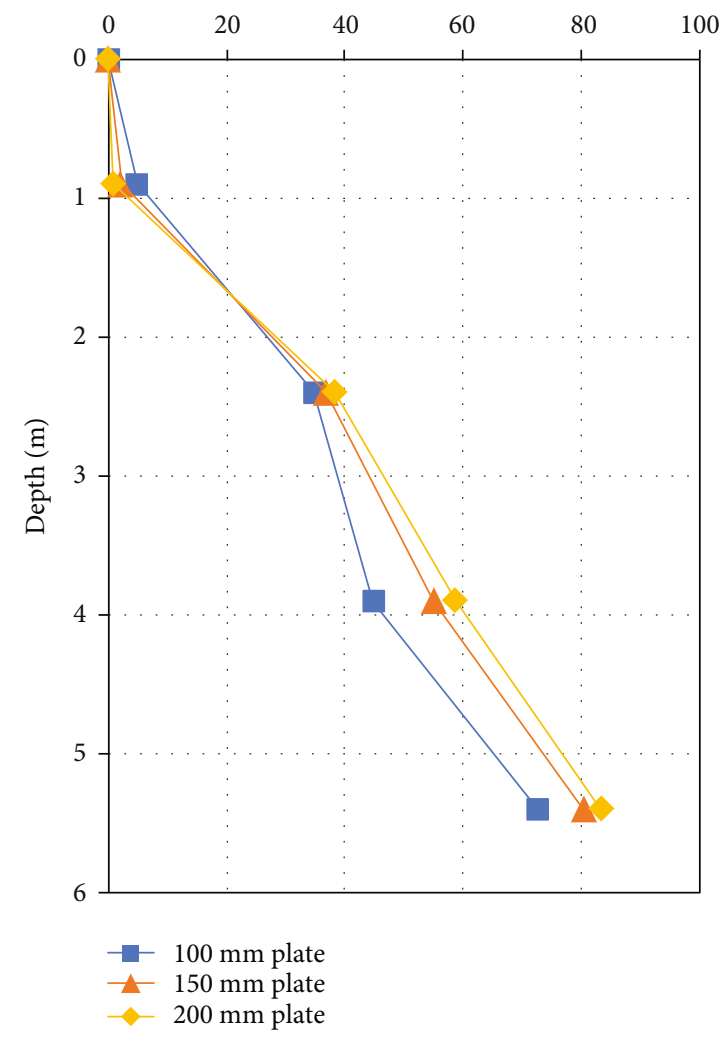

(c) Soil pressure on steel box shield of $100 \mathrm{~mm} \emptyset$ struts

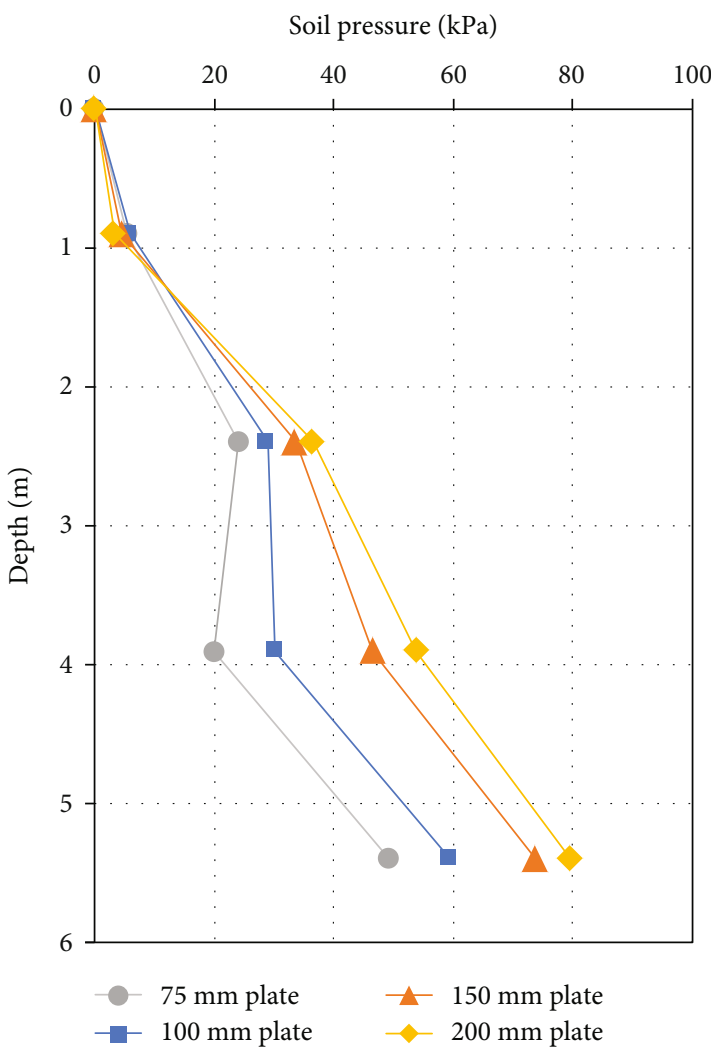

(b) Soil pressure on aluminum box shield of $200 \mathrm{~mm} \emptyset$ struts Soil pressure $(\mathrm{kPa})$

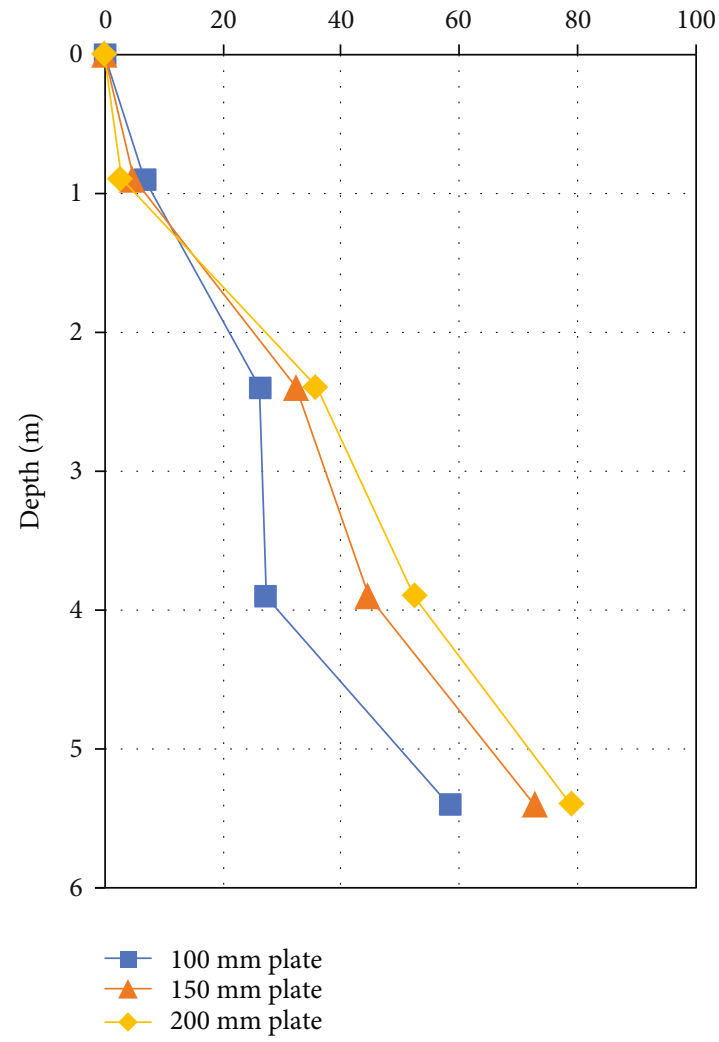

(d) Soil pressure on aluminum box shield of $100 \mathrm{~mm} \emptyset$ struts

Figure 10: Soil pressure (Louiseville clay) on steel and aluminum trench box shields with different plate thicknesses. 


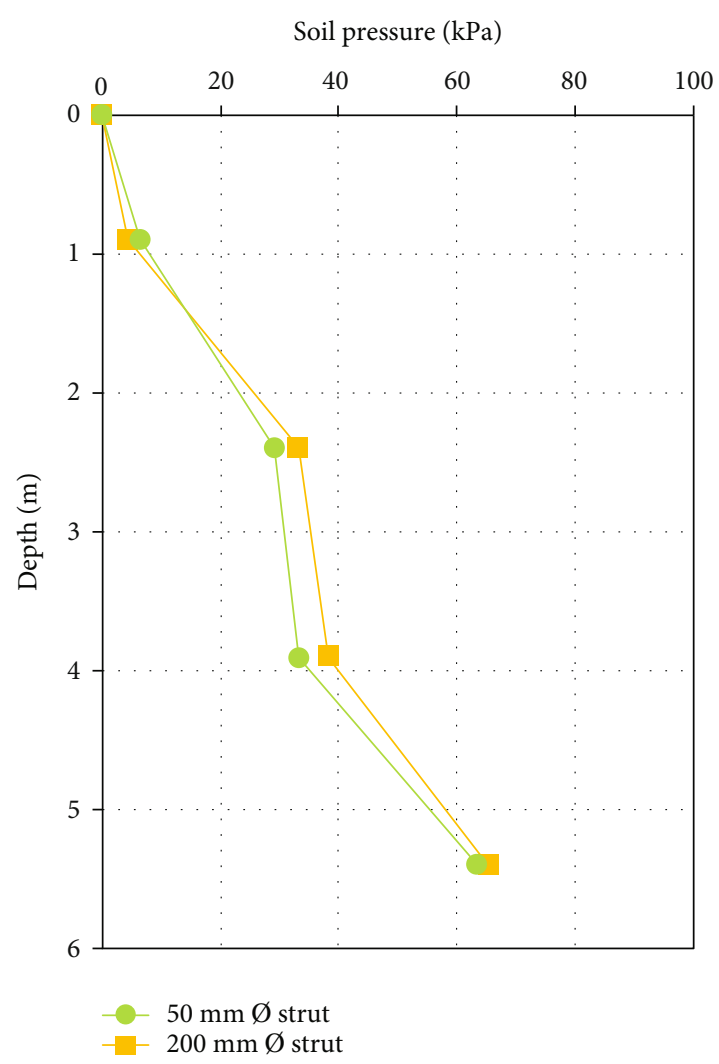

(a) Change of strut diameter in steel box shield with $75 \mathrm{~mm}$ wall Soil pressure $(\mathrm{kPa})$

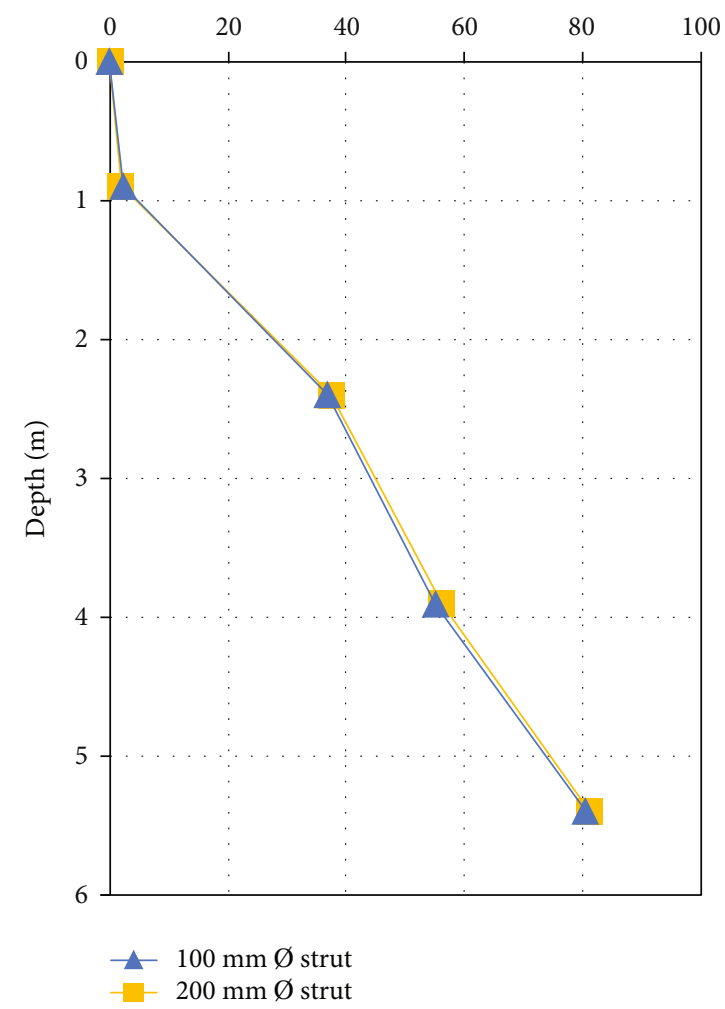

(c) Change of strut diameter in steel box shield with $150 \mathrm{~mm}$ wall

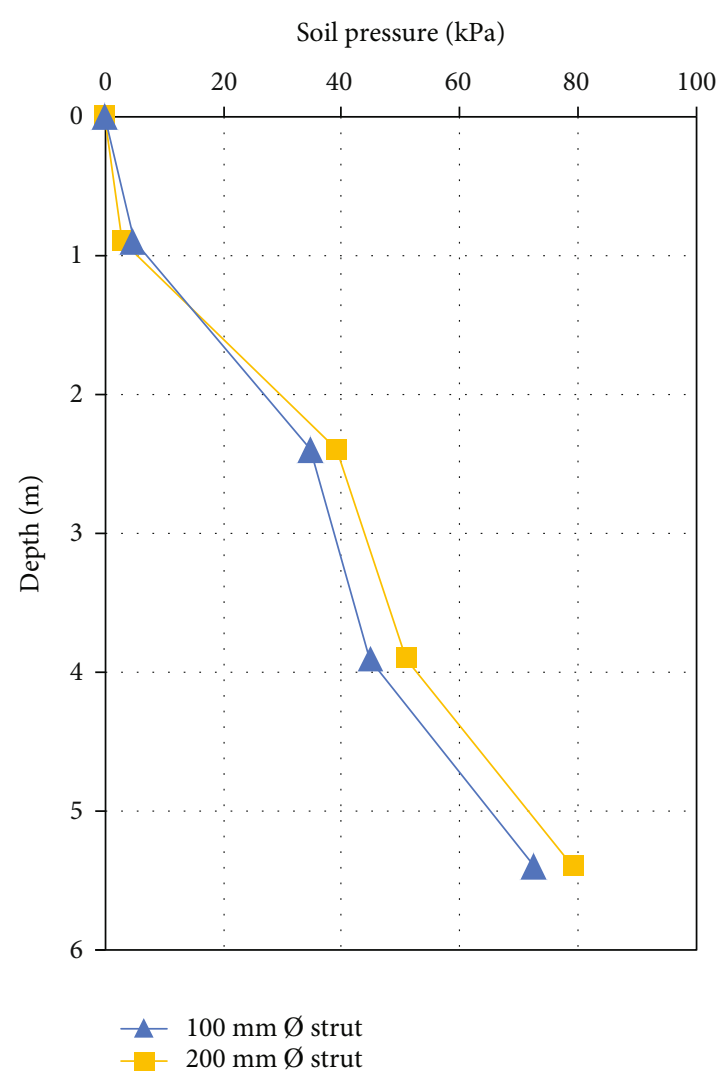

(b) Change of strut diameter in steel box shield with $100 \mathrm{~mm}$ wall Soil pressure $(\mathrm{kPa})$

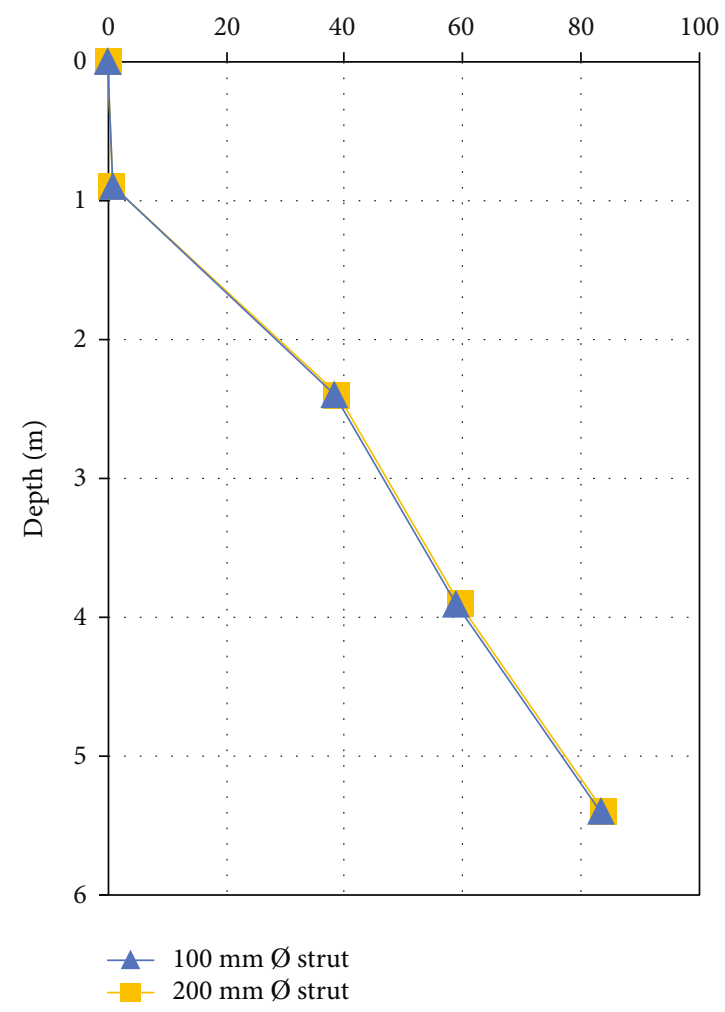

(d) Change of strut diameter in steel box shield with $200 \mathrm{~mm}$ wall

Figure 11: Soil pressure (Louiseville clay) on steel trench box shields with different plate thicknesses and strut diameters. 


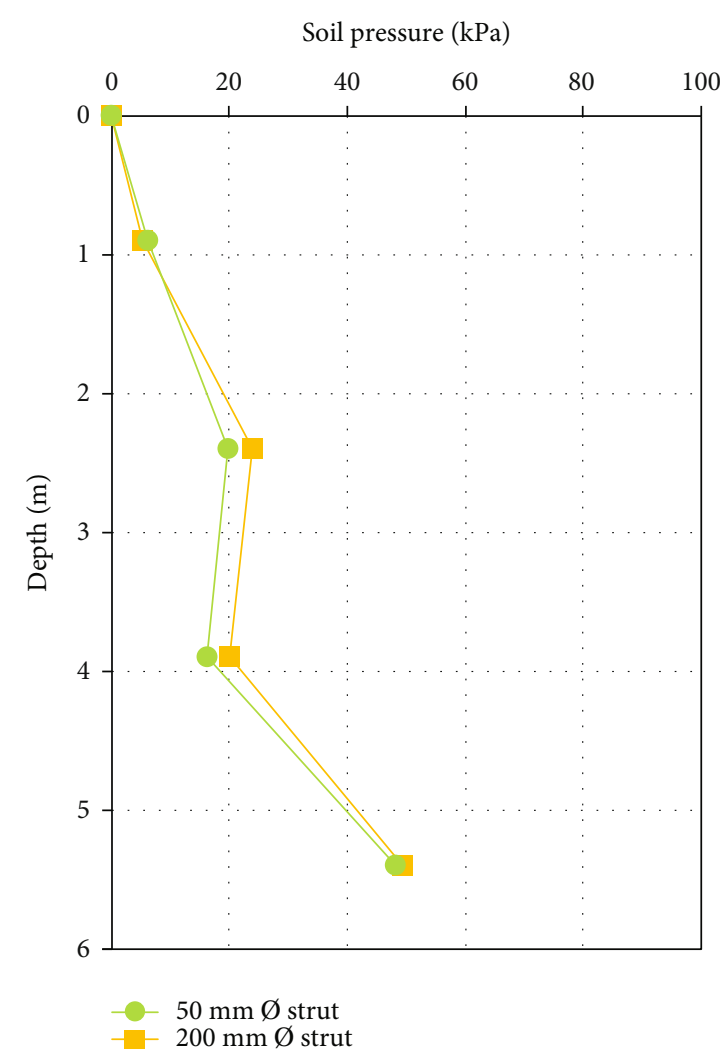

(a) Change of strut diameter in aluminum box shield with $75 \mathrm{~mm}$ wall Soil pressure $(\mathrm{kPa})$

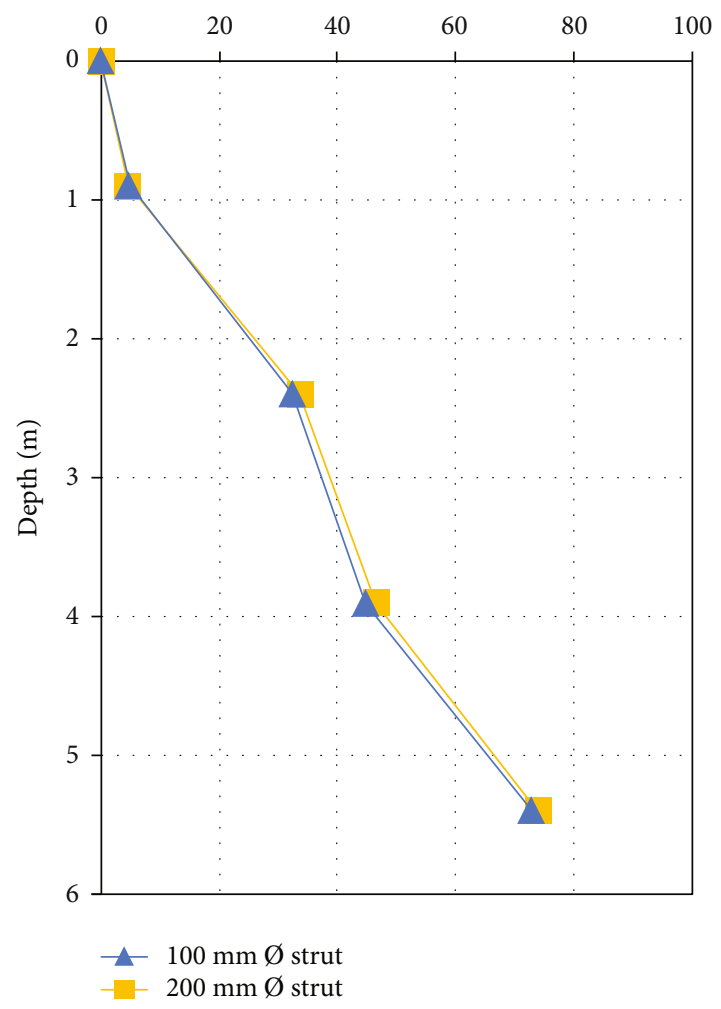

(c) Change of strut diameter in aluminum box shield with $150 \mathrm{~mm}$ wall

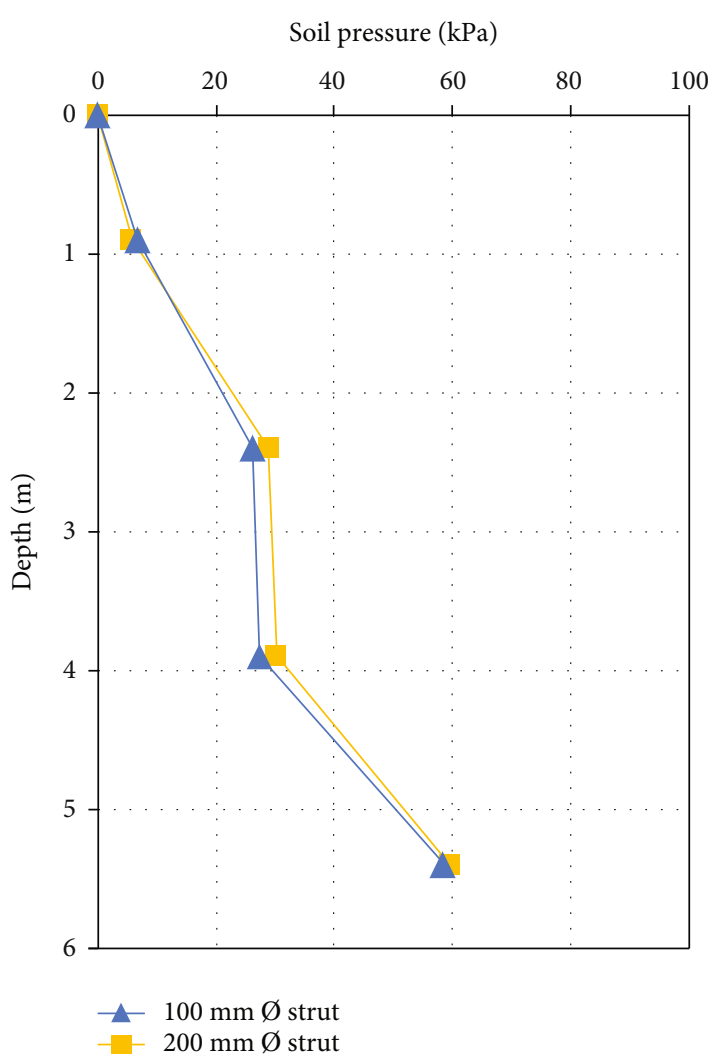

(b) Change of strut diameter in aluminum box shield with $100 \mathrm{~mm}$ wall Soil pressure $(\mathrm{kPa})$

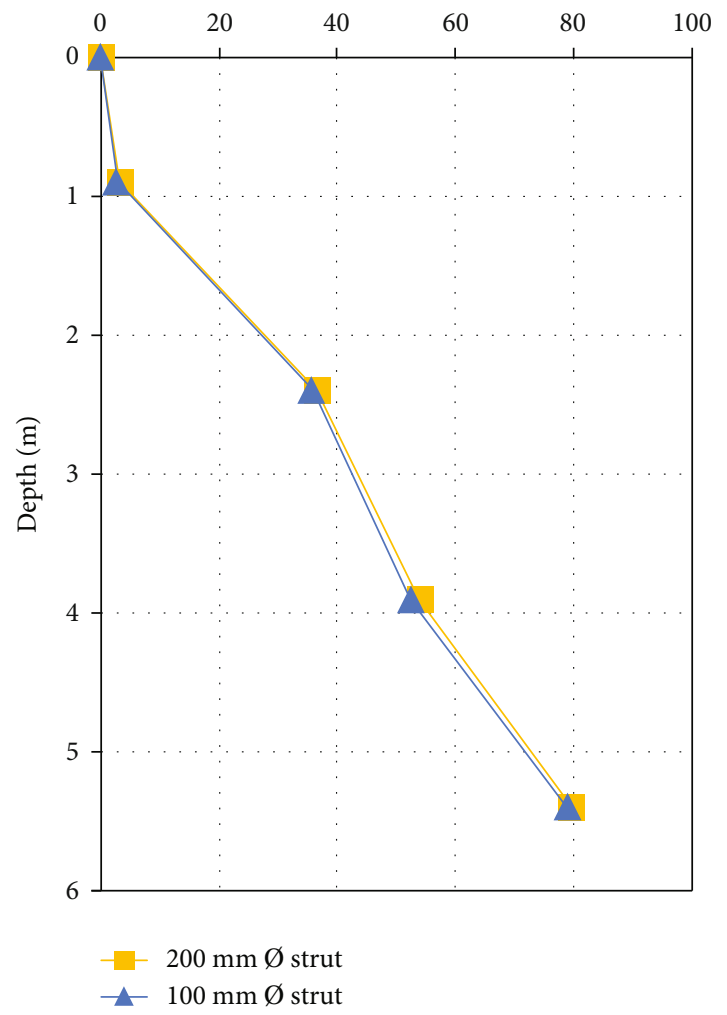

(d) Change of strut diameter in aluminum box shield with $200 \mathrm{~mm}$ wall

FIGURE 12: Soil pressure (Louiseville clay) on aluminum trench box shields with different plate thicknesses and strut diameters. 
9.5\% decrease on aluminum trench box shields for the same type of soil

\section{Data Availability}

Data that support the findings of this study are available from the corresponding author upon reasonable request.

\section{Conflicts of Interest}

The authors declare that they have no conflicts of interest.

\section{Acknowledgments}

The financial support of the Institut de Recherche RobertSauvé en Santé et en Sécurité du Travail (IRSST) through operating grant 0099-5290 is gratefully acknowledged. The help and participation from Laval University (Quebec, Canada) for the experimental field tests and Louiseville clay characterization are also gratefully acknowledged.

\section{References}

[1] D. Potts and A. Fourie, "A numerical study of the effects of wall deformation on earth pressures," International Journal for Numerical and Analytical Methods in Geomechanics, vol. 10, no. 4, pp. 383-405, 1986.

[2] J.-M. Zhang, Y. Shamoto, and K. Tokimatsu, "Evaluation of earth pressure under any lateral deformation," Soils and Foundations, vol. 38, no. 1, pp. 15-33, 1998.

[3] K. Karlsrud and L. Andresen, "Loads on braced excavations in soft clay," International Journal of Geomechanics, ASCE, vol. 5, no. 2, pp. 107-113, 2005.

[4] A. Macnab, Earth Retention Systems Handbook, McGraw-Hill, United States of America, 2002.

[5] OSHA, "Excavations: hazard recognition in trenching and shoring," in OSHA Technical Manual (OTM), U.S. Department of Labor, Washington, DC, 2015.

[6] W. Rankine, On the Mathematical Theory of the Stability of Earth-Work and Masonry, The Royal Society of London, London, 1857.

[7] K. Terzaghi and R. B. Peck, Soil Mechanics in Engineering Practice, Wiley, New York, 2nd edition, 1967.

[8] F. Y. Yokel, L. R. Tucker, and L. C. Reese, Soil Classification for Construction Practice in Shallow Trenching, National Bureau of Standards, Washington, DC, 1980.

[9] CFEM, Canadian Foundation Engineering Manual, Canadian Geotechnical Society, Vancouver, 4th edition, 2006.

[10] D. Goldberg, W. Jaworski, and W. Gordon, "Lateral support systems and underpinning," in Volume I. Design and Construction, Federal Highway Administration (FHWA), Washington D.C., 1976.

[11] Y. M. Hashash and A. J. Whittle, "Ground movement prediction for deep excavations in soft clay," Journal of Geotechnical Engineering, ASCE, vol. 122, no. 6, pp. 474-486, 1996.

[12] N. Benmebarek, H. Labdi, and S. Benmebarek, "A numerical study of the active earth pressure on a rigid retaining wall for various modes of movements," Soil Mechanics and Foundation Engineering, vol. 53, no. 1, pp. 39-45, 2016.

[13] L. Bjerrum, C. J. F. Clausen, and J. M. Duncan, Earth Pressures on Flexible Structures: A State-of-the-art Report to the Vth
European Conference on Soil Mechanics and Foundation Engineering, Norwegian Geotechnical Institute, Madrid, 1972.

[14] Y. M. A. Hashash and A. J. Whittle, "Mechanisms of load transfer and arching for braced excavations in clay," Journal of Geotechnical Engineering, vol. 128, no. 3, pp. 187-197, 2002.

[15] N. Mortensen and L. Andresen, "Analysis of undrained excavation in anisotropic clay," in Int. Workshop on Geotechnics of Soft Soils Theory and Practice, pp. 245-250, Noordwijkerhout, The Netherlands, 2003.

[16] L. S. Bryson and D. G. Zapata-Medina, "Method for estimating system stiffness for excavation support walls," Journal of Geotechnical and Geoenvironmental Engineering, vol. 138, no. 9, pp. 1104-1115, 2012.

[17] M. Alam, O. Chaallal, and B. Galy, "Protection practices for trench and excavation in Quebec sensitive clay soils: review of codes guidelines, and research needs," Safety Science, vol. 131, pp. 904-918, 2020.

[18] S. M. LaBaw, Earth Pressure Determination in Trench Rescue Shoring Systems, Thesis Rreport for Doctor of Philosophy, University of Maryland, College Park, 2009.

[19] M. Alam, O. Chaallal, and B. Galy, "Flexible temporary shield in soft and sensitive clay: 3D FE modeling of experimental field test," Modelling and Simulation in Engineering, vol. 2021, 15 pages, 2021.

[20] S. Bentley, Plaxis Material Models Manual, Bentley Systems, Exton, PA, 2017.

[21] Y. Arai, O. Kusakabe, O. Murata, and S. Konishi, "A numerical study on ground displacement and stress during and after the installation of deep circular diaphragm walls and soil excavation," Computers and Geotechnics, vol. 35, no. 5, pp. 791$807,2008$.

[22] R. J. Finno, J. T. Blackburn, and J. F. Roboski, “Three-dimensional effects for supported excavations in clay," Journal of Geotechnical and Geoenvironmental Engineering, vol. 133, no. 1, pp. 30-36, 2007.

[23] Y. Hou, J. Wang, and L. Zhang, "Finite-element modeling of a complex deep excavation in Shanghai," Acta Geotechnica, vol. 4, no. 1, pp. 7-16, 2009.

[24] C. Y. Ou, B. Y. Shiau, and I. W. Wang, "Three-dimensional deformation behavior of the Taipei National Enterprise Center (TNEC) excavation case history," Canadian Geotechnical Journal, vol. 37, no. 2, pp. 438-448, 2000.

[25] P. Hsieh and C. Ou, "Shape of ground surface settlement profiles caused by excavation," Canadian Geotechnical Journal, vol. 35, no. 6, pp. 1004-1017, 1998.

[26] W. Allen Marr and M. Hawkes, "Displacement-based design for deep excavations," in Earth retention conference (ER) 2010, pp. 82-100, Bellevue, Washington, 2010.

[27] M. Alam, O. Chaallal, and B. Galy, "Field test of temporary excavation wall support in sensitive clay," ISSMGE International Journal of Geoengineering Case Histories (IJGCH), vol. 6 , no. 2, pp. 18-40, 2021.

[28] H. B. Seed and I. M. Idriss, Soil Moduli and Damping Factors for Dynamic Response Analyses, U.S. Department of Commerce, National Technical, Information Service, Berkeley, California, 1970.

[29] H. Matsuzawa and H. Hazarika, "Analyses of active earth pressure against rigid retaining wall subjected to different modes of movement," Soil and Foundations, vol. 6, no. 3, pp. 51-65, 1996. 
[30] H. Poulos, J. Carter, and J. Small, Foundations and Earth Retaining Structures-Research and Practice, AA Balkema, Netherlands, 2002.

[31] J. Jaky, "The coefficient of earth pressure at rest," Journal of the Society of Hungarian Architects and Engineers, vol. 78, no. 22, pp. 355-358, 1944.

[32] K. Hamouche, S. Leroueil, M. Roy, and A. Lutenegger, "In situ evaluation of $\mathrm{K}_{0}$ in eastern Canada clays," Canadian Geotechnical Journal, vol. 32, no. 4, pp. 677-688, 1995.

[33] S. Dourlet, "Étude expérimentale de deux excavations à Louiseville," M. Sc. thesis, Université Laval, Québec, Canada, 2020.

[34] J. F. Zanavelo, "Excavation dans un dépôt d'argile sensible du Québec: comportement et modélisation," in Excavation in a sensitive Quebec clay deposit: behaviour and modeling, Ph.D. dissertation thesis, Université Laval, Québec, Canada, 2021. 